Review

\title{
Connexins: sensors and regulators of cell cycling
}

\author{
Mathieu Vinken ${ }^{\mathrm{a}, *, 1}$, Elke Decrock ${ }^{\mathrm{b}, 2}$, Elke De Vuyst ${ }^{\mathrm{b}}$, Raf Ponsaerts ${ }^{\mathrm{c}}$, Catheleyne D'hondt ${ }^{\mathrm{c}, 1}$, \\ Geert Bultynck $^{\mathrm{c}}$, Liesbeth Ceelen ${ }^{\mathrm{a}}$, Tamara Vanhaecke ${ }^{\mathrm{a}, 1}$, Luc Leybaert $^{\mathrm{b}}$, Vera Rogiers ${ }^{\mathrm{a}}$ \\ a Department of Toxicology, Faculty of Medicine and Pharmacy, Vrije Universiteit Brussel, Laarbeeklaan 103, B-1090 Brussels, Belgium \\ b Department of Basic Medical Sciences-Physiology group, Faculty of Medicine and Health Sciences, Universiteit Gent, De Pintelaan 185, B-9000 Ghent, Belgium \\ c Department of Molecular Cell Biology-Laboratory of Molecular and Cellular Signalling, Faculty of Medicine, Katholieke Universiteit Leuven, Campus Gasthuisberg O/N-1 bus 802, \\ Herestraat 49, B-3000 Leuven, Belgium
}

\section{A R T I C L E I N F O}

\section{Article history:}

Received 12 July 2010

Received in revised form 18 August 2010

Accepted 20 August 2010

Available online 27 August 2010

\section{Keywords:}

Connexin

Pannexin

Hemichanne

Gap junction

Cell cycle

\begin{abstract}
A B S T R A C T
It is nowadays well established that gap junctions are critical gatekeepers of cell proliferation, by controlling the intercellular exchange of essential growth regulators. In recent years, however, it has become clear that the picture is not as simple as originally anticipated, as structural precursors of gap junctions can affect cell cycling by performing actions not related to gap junctional intercellular communication. Indeed, connexin hemichannels also foresee a pathway for cell growth communication, albeit between the intracellular compartment and the extracellular environment, while connexin proteins as such can directly or indirectly influence the production of cell cycle regulators independently of their channel activities. Furthermore, a novel set of connexin-like proteins, the pannexins, have lately joined in as regulators of the cell proliferation process, which they can affect as either single units or as channel entities. In the current paper, these multifaceted aspects of connexin-related signalling in cell cycling are reviewed.
\end{abstract}

Crown Copyright @ 2010 Published by Elsevier B.V. All rights reserved.

\section{Contents}

1. Introduction . . . . . . . . . . . . . . . . . . . . . . . . . . . . . . . . . . . . . . . 14

2. Connexins and their channels: basic concepts . . . . . . . . . . . . . . . . . . . . . . . . . . . . . . . . 14

2.1. Structural properties. . . . . . . . . . . . . . . . . . . . . . . . . . . . . . . . . . . . . . . 14

2.2. Functional properties . . . . . . . . . . . . . . . . . . . . . . . . . . . . . . . . . . . . 14

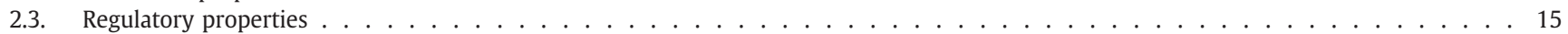

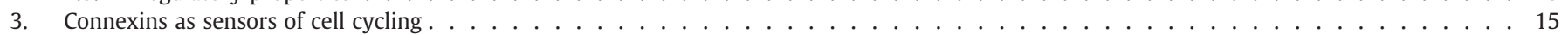

3.1. Effects of cell proliferation on connexin-related signalling . . . . . . . . . . . . . . . . . . . . . . . . . . . . . . . 15

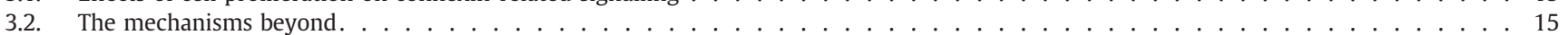

3.2.1. Transcriptional modulation of connexin expression . . . . . . . . . . . . . . . . . . . . . . . . . . . . . . 15

3.2.2. Posttranslational modulation of connexin channel activity. . . . . . . . . . . . . . . . . . . . . . . . . . . . . 16

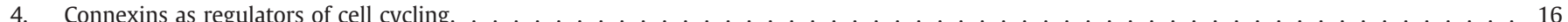

4.1. Effects of connexin-related signalling on cell proliferation . . . . . . . . . . . . . . . . . . . . . . . . . . . . . . . . . . . . 16

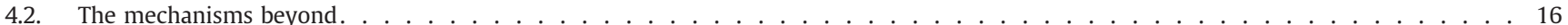

4.2.1. Mechanisms related to connexin channel formation. . . . . . . . . . . . . . . . . . . . . . . . . . . . . 16

4.2.2. Mechanisms not related to connexin channel formation. . . . . . . . . . . . . . . . . . . . . . . . . 17

Abbreviations: AP-1, activator protein 1; ATP, adenosine triphosphate; cADPr, cyclic adenosine diphosphate ribose; cAMP, cyclic adenosine monophosphate; CCN, Cyr61, connective tissue growth factor (CTGF) and NOV; CD38, cluster of differentiation 38; cdk, cyclin-dependent kinase; Cip/Kip, cdk inhibitory protein/kinase inhibitor protein; Cx, connexin; CxRE, connexin response element; Cyr61, cysteine rich 61; Dlgh1, discs-large homolog 1; EGF, epidermal growth factor; ERK1/2, extracellular regulated kinase 1/2; FGF1/ 2, fibroblast growth factor $1 / 2$ (acidic/basic); G0/1/2 phase, gap 0/1/2 phase; GJIC, gap junctional intercellular communication; IP ${ }_{3}$ inositol trisphosphate; JNK, jun $\mathrm{NH}_{2}$ terminal kinase; MAPK, mitogen-activated protein kinase; M phase, mitosis phase; NAD ${ }^{+}$, nicotinamide adenine dinucleotide; NOV, nephroblastoma overexpressed; Panx, pannexin; PKC, protein kinase C; S phase, DNA synthesis phase; Skp2, S phase kinase-associated protein 2; Sp1, specificity protein 1; UDP, uridine diphosphate; Wnt, Wingless-Int; ZO-1/2, zonula occludens 1/2; ZONAB, ZO-1-associated nucleic acid binding protein

* Corresponding author. Tel.: + 32247745 87; fax: +32 24774582

E-mail address: mvinken@vub.ac.be (M. Vinken).

1 M.V., C.D. and T.V. are postdoctoral research fellows of the Fund for Scientific Research Flanders (FWO-Vlaanderen), Belgium.

${ }^{2}$ E.D. is a doctoral research fellow of the Fund for Scientific Research Flanders (FWO-Vlaanderen), Belgium. 


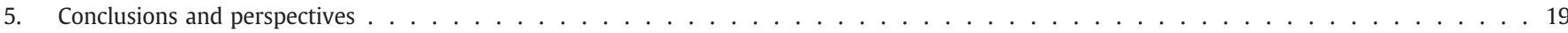

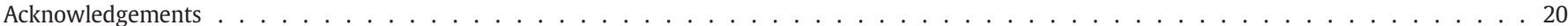

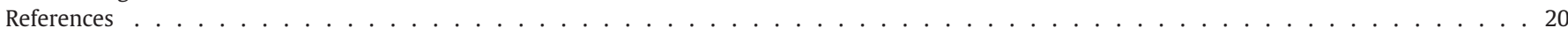

\section{Introduction}

The cell cycle is a well-orchestrated physiological process that drives cell proliferation, cell growth and development. As such, the somatic cell cycle encompasses the mitotic (M) phase, subdivided into the prophase, the metaphase, the anaphase and the telophase, and the interphase. The interphase consists of a first gap (G1) phase, the DNA synthesis (S) phase and the second gap (G2) phase, whereby the former and the latter serve to prepare the cell for the $S$ phase and the $M$ phase, respectively. Cells can exit the cell cycle and either enter a quiescent (G0) phase, in which they can reside for an indefinite period, or undergo terminal differentiation and/or apoptosis. Deviation of physiological cell cycling, as a consequence of homeostatic imbalance, may lead to uncontrolled cell proliferation activity which ultimately might burgeon into carcinogenesis [1-4].

Progression through the subsequent cell cycle phases is coordinated by a series of enzymes composed of a regulatory subunit and a catalytic subunit, namely a cyclin protein and a cyclin-dependent kinase (cdk), respectively. The activity of cdk enzymes is not only regulated by their selective cooperation with cyclins, but also by a number of other factors, including kinases, phosphatases and members of the cdk inhibitory protein/kinase inhibitor protein (Cip/Kip) family. In turn, these intrinsic cell cycle regulators rely on commands triggered by extracellular signals, such as growth factors $[2,4,5]$. At the intercellular signalling platform, control of the cell cycle machinery is mainly accommodated by gap junctions, a group of specialized cell-to-cell junctions composed of connexin proteins [6-10].

In the present paper, a state-of-the-art overview of the role of connexin-related signalling in cell cycling is provided. In the first part, basic concepts with respect to the biology of connexin channels are reviewed. In the second part, the outcome of cell cycling on connexinrelated signalling is discussed, whereas the inverse event, namely the effects of connexin-related signalling on cell cycling, are extensively outlined in the third part. Overall, particular attention is paid to the molecular mechanisms that underlie this interrelationship.

\section{Connexins and their channels: basic concepts}

\subsection{Structural properties}

Morphologically, gap junctions appear as plaques at the cell plasma membrane surface and arise from the docking of two hemichannels (connexons) of adjacent cells, which on their turn are composed of six connexin $(\mathrm{Cx})$ units. The connexin family comprises as many as twenty isoforms in mammals. They all share an identical molecular architecture, consisting of four membrane-spanning domains, two extracellular loops, one intracellular loop, one cytoplasmic $\mathrm{N}$-terminal tail and one cytoplasmic C-terminal tail (Fig. 1). Connexins are named after their molecular weight and are expressed in a tissue-specific and even in a cellspecific manner. Thus, the most abundant connexin species in the human body has a predicted weight of $43 \mathrm{kDa}$ and is therefore designated $\mathrm{Cx} 43$ [6,7,11-13]. Connexins interact with a number of other cellular proteins, including scaffolding proteins, junctional proteins, cytoskeletal proteins, trafficking regulators, posttranslational modifiers and growth regulators, all of which may affect connexin metabolism and functionality $[11,14]$.

\subsection{Functional properties}

Gap junctions provide an essential pathway for the intercellular exchange of small and hydrophilic molecules, including glucose, glutamate, glutathione, cyclic adenosine monophosphate (cAMP), adenosine triphosphate (ATP), inositol trisphosphate $\left(\mathrm{IP}_{3}\right)$, and ions, like calcium, sodium and potassium $[15,16]$. The biophysical permeation characteristics of these substances rely on the nature of the connexin species that form the gap junction $[15,17]$. For instance, ATP is more able to pass through Cx43-based gap junctions, compared with channels composed of Cx32 [18]. Obviously, numerous, if not all, physiological processes are driven by the substances that are conveyed via these channels, and hence gap junctional intercellular communication (GJIC) is considered as a key mechanism in the maintenance of tissue homeostasis $[6,7,13,16]$. In the last decade, it has become clear that hemichannels in

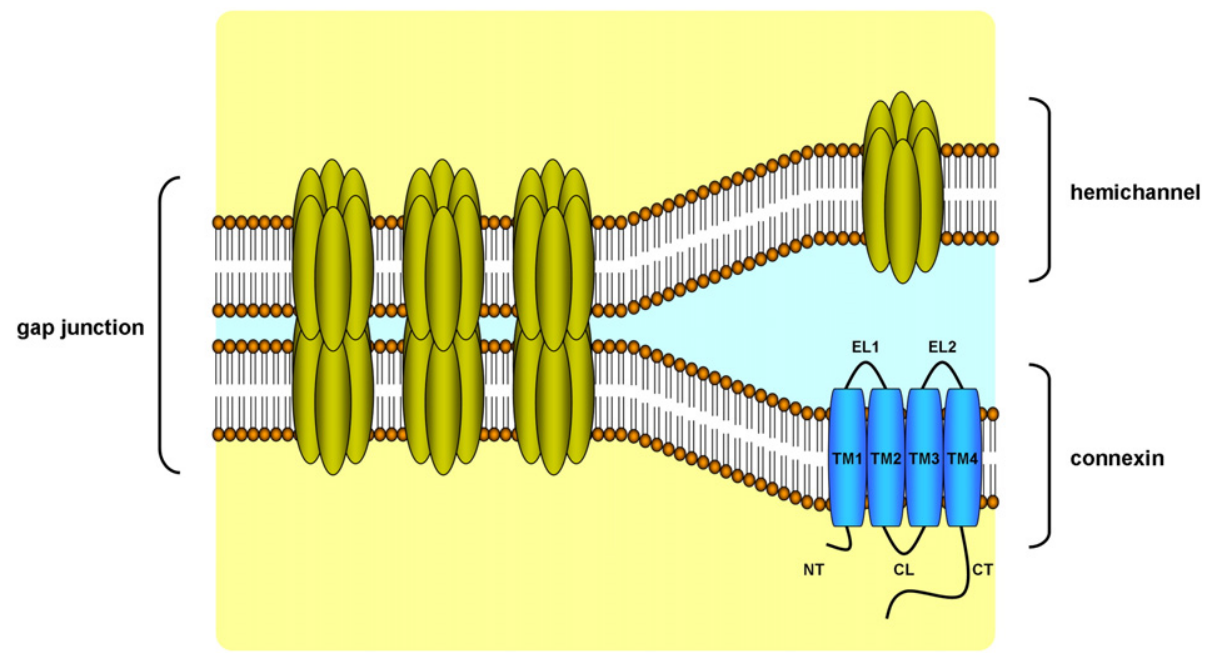

Fig. 1. Molecular architecture of gap junctions. Gap junctions are grouped in plaques at the cell plasma membrane surface and are composed of twelve connexin proteins, organized as two hexameric hemichannels or connexons of two apposed cells. The connexin protein as such is organized as four membrane-spanning domains (TM1-4), two extracellular loops (EL1-2), one cytoplasmic loop (CL), one cytoplasmic amino tail (NT) and one cytoplasmic carboxy tail (CT). 
non-junctional areas at the cell plasma membrane surface also can function as transmembrane channels. In fact, connexons foresee a pathway for communication between the intracellular compartment and the extracellular environment. The substances that travel through hemichannels are quite similar to those implied in GJIC, namely ATP, nicotinamide adenine dinucleotide $\left(\mathrm{NAD}^{+}\right)$, glutamate, glutathione and prostaglandins [12,16,19-21].

\subsection{Regulatory properties}

A labyrinth of mechanisms underlies the regulation of the connexin life cycle and activity. Instant control (i.e. second/minute range) of connexin channel functionality by the process of channel gating is governed by a number of factors, including transmembrane voltage, calcium ions and hydrogen ions $[6,7,13]$. Undoubtedly, phosphorylation has gained most attention in this respect. All connexins, with the exception of $\mathrm{Cx} 26$, are phosphoproteins. The outcome of the phosphorylation event, mainly occurring at the C-terminal connexin tail, depends on both the identity of the connexin species and the kinase type [22,23]. Regulation of GJIC and hemichannel activity over the long-term (i.e. hour range) basically concerns peritranscriptional control of connexin expression. The structure of most connexin genes is rather simple and consists of a first exon, containing the $5^{\prime}$-untranslated region which is separated by an intron from a second exon, bearing the complete coding sequence and the $3^{\prime}$-untranslated region $[11,24,25]$. Connexin gene transcription is ruled by conventional cis/trans actions, involving both ubiquitous transcription factors, like specificity protein 1 (Sp1) and activator protein 1 (AP-1), and tissue-specific transcription factors, such as hepatocyte nuclear factor 1 [25]. Epigenetic mechanisms, including histone acetylation and DNA methylation, predominate the pretranscriptional platform of connexin expression [6,25]. Recently, microRNA species have been described as novel regulators of connexin expression at the posttranscriptional level [26-31].

\section{Connexins as sensors of cell cycling}

\subsection{Effects of cell proliferation on connexin-related signalling}

It has been first reported already a few decades ago that mitotic cells, such as in early mouse and Xenopus laevis embryos, display reduced gap junction-based intercellular coupling, not only among themselves, but also with interphasic cells [32-37]. In course of time, a broad variety of empirical models has been used to scrutinize the physiological connection between connexin-related signalling and cellular proliferation, though a frequently addressed experimental setting includes the regenerating liver. The adult liver displays very low proliferative activity under normal conditions. Upon partial hepatectomy, however, the remaining liver lobes start to grow and the original size becomes restored within a week $[38,39]$. Most reports describe transiently increased GJIC and gap junction numbers in the G1 phase, followed by a drastic decrease upon initiation of the $S$ phase of the hepatocyte cell cycle. Similar alterations are observed at the level of Cx32 expression and in many cases in Cx26 levels, whereas Cx43 largely remains unaffected [40-51]. Other connexins present in hepatic tissue, including $\mathrm{Cx} 37$ and $\mathrm{Cx} 40$, are clearly upregulated during liver regeneration [52]. Analogous findings are produced in in vitro systems of hepatocyte proliferation, namely mitogen-stimulated primary hepatocyte cultures [40-44,53,54]. Differential expression patterns of connexins, in casu Cx37, Cx39, Cx40, Cx43 and Cx45, are also noticed during rat muscle regeneration following crush injury [55] and notexin-induced myonecrosis [56,57]. In regenerating rat tracheal epithelium, gap junction numbers increase in the interphase and decrease during the $\mathrm{M}$ phase [58]. Cultured normal human mammary epithelial cells display moderate $\mathrm{Cx} 26$ production during the G1 phase and the early S phase, but high levels in the late $S$ phase and the G2 phase. Cx43, by contrast, is constitutively expressed at a uniform low level throughout the cell cycle [59]. In proliferating cells of the murine neocortex, Cx26 expression increases from the $\mathrm{S}$ phase to the early G1 phase and remains moderately high throughout the rest of the cell cycle. $\mathrm{Cx} 43$ production is highest in the $S$ phase and the G2 phase and decreases towards the G1 phase. This corresponds with maximal coupling during DNA synthesis and the G2 phase, uncoupling in the $\mathrm{M}$ phase and recoupling in the $\mathrm{G} 1$ phase and the $\mathrm{S}$ phase $[60,61]$. With respect to the mitotic process as such, GJIC drastically drops at the onset of the prophase, and remains low throughout the metaphase, the anaphase and the telophase. Resumption of GJIC between newly divided cells and surrounding cells occurs slowly after cytokinesis [34,62]. A plethora of additional reports have described alterations in GJIC and connexin expression during cell cycling in somatic cells both in physiological and pathological conditions, and although conflicting results have been published [15,63-68], the overall outcome of these studies is that an inverse relationship exists between cell proliferation and gap junction activity [69-74]. A particular case includes the meiotic cell cycle in germ cells, especially in oocytes, which is initiated during embryonic life. A first meiotic block occurs at a G2-like phase of the cell cycle (i.e. the prophase of the first meiosis), and is associated with the establishment of GJIC. Upon gonadotropin stimulation during puberty, the oocytes resume meiosis, which is preceded by a drastic downregulation of $\mathrm{Cx} 43$ expression and GJIC. This allows completion of the first meiotic division, followed by the second metaphase, where the oocytes remain arrested until activation by a spermatozoon $[75,76]$.

\subsection{The mechanisms beyond}

\subsubsection{Transcriptional modulation of connexin expression}

A clear-cut way to interfere with connexin-related signalling upon cell growth commitment concerns direct modulation of the expression of its constituents at the most upstream regulatory level. A myriad of cell proliferation-related signalling cascades are known to affect connexin gene transcription. The mitogen-activated protein kinase (MAPK) signal transduction pathway has received considerable attention in this context. As much as six different MAPK cascades have been characterized in mammals, of which the most extensively studied ones include the extracellular regulated kinase (ERK) pathway, the jun $\mathrm{NH}_{2}$ terminal kinase (JNK) pathway and the p38 MAPK pathway. These signalling cascades can be activated by a number of extracellular stimuli, such as hormones and growth factors, and can influence the transcription of cell cycle genes in a straightforward manner by triggering phosphorylation of the protooncogenes c-jun and c-fos $[77,78]$. The latter dimerize to form the transcription factor AP-1, which is known to bind the promoter region of the Cx43 gene [25]. Heat shock protein 90 and c-myc also directly interact with the $\mathrm{Cx} 43$ gene promoter upon induction of MAPK signalling [79]. Despite the generally established negative correlation between cell proliferation and GJIC, however, MAPK pathways preferentially upregulate $\mathrm{Cx} 43$ gene transcription. Indeed, induction of cell proliferation by angiotensin II and insulin-like growth factor 1 in human saphenous vein smooth muscle cell cultures is associated with increased GJIC and Cx43 expression, whereby the latter is mediated by ERK1/2, p38 MAPK and c-jun $[80,81]$. Both insulin-like growth factor 1 and phenylephrine also upregulate $\mathrm{Cx} 43$ gene transcription in an ERK/p38 MAPK-dependent way in human corneal epithelial cells [82] and neonatal rat cardiomyocytes [83], respectively. Likewise, stimulation of cell proliferation by basic fibroblast growth factor (FGF2) in cultures of mouse cortical neural progenitor cells is accompanied by enhanced cell-to-cell coupling and an elevated Cx43 mRNA content, which is facilitated by ERK1/2 $[63,84]$. By contrast, transforming growth factor- $\beta$ suppresses proliferation of murine mammary gland epithelial cells, but still $\mathrm{Cx} 43$ gene transcription becomes promoted in a p38 MAPK/c-jun-dependent manner [85]. A MAPK signalling cascade is also activated by luteinizing hormone 
upon meiotic resumption in rat oocytes, though this is allied with decreased Cx43 mRNA levels $[75,86]$.

\subsubsection{Posttranslational modulation of connexin channel activity}

At the utter downstream platform of connexin expression, phosphorylation represents a major mechanism for regulating connexin-based signalling during cell cycling. Thus, upon proliferation of human T cells, Cx43 phosphorylation at serine368 strongly increases [87]. In serum-stimulated rat liver cells, progression from the G0 phase to the $S$ phase is related to protein kinase C (PKC)dependent phosphorylation of $\mathrm{Cx} 43$ on serine residues and disruption of GJIC, but not with changes in Cx43 mRNA content [88]. In primary cultures of neonatal rat cardiomyocytes, PKC-mediated phosphorylation of $\mathrm{Cx} 43$ at serine262 in response to growth factor stimulation was found to regulate DNA synthesis [89,90]. PKC also phosphorylates $\mathrm{Cx} 43$ at serine368 during the $\mathrm{S}$ phase and the G2/M cell cycle transition in normal rat kidney epithelial cells. This is associated with cytosolic redistribution of Cx43 and subsequent reduced GJIC [91]. Another kinase involved in connexin phosphorylation during cell cycling is cdk1/cyclin B complex, which controls the G2/M cell cycle transition. In several cell types, cdk1/cyclin B-mediated phosphorylation of $\mathrm{Cx} 43$ is highest at the $\mathrm{G} 2 / \mathrm{M}$ cell cycle transition, yielding a mitosis-specific Cx43 phosphoform, called Cx43m [36] or Cx43P3 $[33,92]$. This particular $\mathrm{Cx} 43$ phosphoform preferentially localizes in the cytosol, thus explaining the reduced GJIC activity observed in mitotic cells. Melchheier and co-workers further showed that the cell division cycle $25 \mathrm{~A}$ phosphatase, known to regulate cdk1 activity and the G1/S cell cycle transition, is involved in the ERK1/2-dependent phosphorylation of $\mathrm{Cx} 43$ and GJIC during cell cycling [93]. MAPK members can indeed directly phosphorylate connexin proteins in addition to their acknowledged effects on connexin gene transcription. For instance, the dynamic changes in gap junction formation during hepatocyte proliferation in vivo and in vitro are controlled, at least in part, by p38 MAPK-mediated phosphorylation of $\mathrm{C} \times 32$ $[42,44,54]$. In rat oocytes, luteinizing hormone disrupts GJIC prior to meiotic resumption, which is associated with ERK1/2-assisted phosphorylation of $\mathrm{Cx} 43$ at serine255, serine262, serine279 and serine282 [94,95]. A vast number of studies have outlined phosphorylation of $\mathrm{Cx} 43$ by MAPK members and consequent downregulation of GJIC, whether or not directly induced by growth factors [93,96-103]. Epidermal growth factor (EGF) activates cell proliferation and simultaneously inhibits GJIC in mouse embryonic stem cells. In fact, EGF, after binding to its receptor, triggers PKC, ERK1/2 and p38 MAPK which subsequently phosphorylate $\mathrm{Cx} 43$. This results in elevated levels of c-fos, c-jun and c-myc that on their turn activate the expression of cyclin D1, cyclin E, cdk4 and cdk2 and inactivate the production of the cell cycle inhibitors $\mathrm{p} 21^{\mathrm{Cip} 1}$ and $\mathrm{p} 27^{\mathrm{Kip} 1}$ [104]. A similar mechanism underpins the repressing effects of the adenosine analogue $5^{\prime}-N$-ethylcarboxamide on GJIC in these cells. Thus, $5^{\prime}-N$ ethylcarboxamide induces $\mathrm{Cx} 43$ hyperphosphorylation, involving ERK, p38 MAPK and JNK pathways, which results in the downregulation of GJIC. The outcome of this signalling cascade is an induction of proliferation, as may be evidenced by increased expression of cdk2, cdk4, cyclin E, cyclin D1 and an elevated S phase cell population number [105]. Interestingly, growth factors can have differential and even opposite effects on gap junctions and hemichannels. FGF2, for instance, inhibits gap junction activity but stimulates ATP release through hemichannels in Cx43-overexpressing rat glioma cells [106]. Reverse regulation of gap junctions and hemichannels composed of $\mathrm{Cx} 43$ has also been observed in primary mouse astrocyte cultures and is mediated by p38 MAPK [107]. In addition, activation of p38 MAPK underlies the FGF1-induced increased membrane permeability via $\mathrm{Cx} 43$-based hemichannels in human cervical cancer cells [108]. It has been suggested that switching between GJIC and hemichannel signalling through different regulation may serve to optimize cellular responses to newly occurring (patho)physiological conditions [106], in casu cell growth.

\section{Connexins as regulators of cell cycling}

\subsection{Effects of connexin-related signalling on cell proliferation}

Evidence indicating an active role for connexins and their channels in cell cycle control mainly comes from studies in which connexin expression and activity have been altered by genetic approaches. An abundance of reports have indeed described inhibition, mostly G1/S cell cycle arrests, or induction of (tumor) cell growth upon overexpression or genetic ablation of connexins, respectively [109-148]. Furthermore, expression of connexins protects against spontaneous or chemically induced tumorigenesis and accordingly connexin genes are considered as tumor suppressors $[123,136,140,149-153]$. This negative cell growth control by connexins seems to be a specific rather than a general phenomenon, as not all connexin genes induce cell cycle arrests following their forced expression in cells [115,154-157]. In contrast, several studies have demonstrated that the presence of connexins is indispensable for the enrollment of cell proliferation [158-170]. On top of the already complex nature of the link between connexins and cell cycling comes the issue of the relative importance of their physiological interrelationship. In this respect, Ott and colleagues [171] reported that genetic depletion of Cx26 and Cx32 in hepatocytes does not lead to increased spontaneous liver tumor formation, but only slightly increases the basal proliferation rate. In the regenerating liver of $\mathrm{Cx} 32$ knock-out mice, the $\mathrm{G} 0 / \mathrm{S}$ cell cycle transition, and thus the proliferative activity of the hepatocytes, is not promoted, but the extent of the synchronous initiation and termination of DNA synthesis is altered $[48,150]$. Likewise, cultured astrocytes from Cx43-deficient mice display delayed onset of growth, but the growth rate as such is not altered [168]. Based on these facts, reduction of connexinrelated signalling does not provide a direct signal for cells to divide, but rather permits cell cycle progression upon mitogenic stimulation. In this view, gap junction activity seems to be coordinated with cell growth and serves a purpose other than triggering proliferation. Such purpose may include the functional segregation of the metabolic pools in dividing cells from their quiescent neighbours in order to avoid disruption of the homeostatic balance $[40,41,172]$. A conflicting concept states that connexins fulfil a determinate function in cell cycle control, thus exceeding a merely assisting role in cell growth progression. In support of this idea are not only the numerous aforementioned genetic studies, showing a causal inverse link between cell connexin expression and cell growth control [109-147], but also for instance the finding that in primary cultures of Cx32 knock-out mouse hepatocytes, most cells enter the S phase without mitogenic stimulation, whereas their wild-type counterparts are blocked in the G1 phase in these conditions [173].

\subsection{The mechanisms beyond}

\subsubsection{Mechanisms related to connexin channel formation}

4.2.1.1. Gap junction-dependent mechanisms. It has been demonstrated on several occasions that chemical inhibition of GJIC affects cell cycling. The prototypical gap junction blockers 18 - $\alpha$-glycyrrhetinic acid, heptanol and carbenoxolone were indeed found to suppress mitotic clonal expansion in cultures of mouse adipocytes [174], in human placental villous explant cultures [175] and in rat retinal cells in vivo [176], respectively. Carbenoxolone also attenuates DNA synthesis in cultures of rat hepatic stellate cells, accompanied by the decreased expression of cyclin D1, cyclin D2, cdk2, cdk4 and cdk6 [177]. Cisplatin induces gap junction closure in human lung fibroblasts which is associated with a G1/S cell cycle arrest, elevated p53 expression and initiation of premature senescence [178]. On the other hand, 18 - $\alpha$-glycyrrhetinic acid promotes cell cycling in cultures of rat Sertoli cells [179] and enhances the ability of murine 
megakaryocytes to stimulate proliferation in co-cultured osteoblasts [180]. Furthermore, exposure of primary cultures of rat astrocytes to carbenoxolone increases the $\mathrm{S}$ phase, the $\mathrm{G} 2$ phase and the $\mathrm{M}$ phase cell cycle population numbers and simultaneously decreases the amount of G1 phase and G0 phase cells. This is allied with increased phosphorylation of retinoblastoma protein and enhanced expression levels of cyclin D1 and cyclin D3 [181]. In rat ovarian follicles, carbenoxolone triggers reinitiation of meiosis and oocyte maturation [182]. Clearly, gap junctions foresee a pathway for the direct intercellular exchange of positive and negative cell growth regulators. However, the biochemical identity of these messengers largely remains to be clarified. A first plausible candidate in this context includes calcium. Gap junctional propagation of calcium waves in proliferating human keratinocytes is much lower in comparison with that in differentiating keratinocytes in the upper layers of the skin [183]. Additionally, increased intercellular travelling of calcium via gap junctions is thought to underlie the G0/G1 cell cycle block induced by fucoxanthin in human hepatoma cells [184]. A second possible cell growth messenger is cAMP, which is an acknowledged enhancer of p2 $7^{\text {Kip } 1}$ production $[142,144]$. The cAMP content is highest in the G1 phase and decreases prior to $S$ phase entry [185], thus correlating with the downregulation of GJIC at the G1/S cell cycle transition observed in many cell types, such as in proliferating hepatocytes [40-51]. In oocytes, cAMP and guanosine-3',5'-cyclic monophosphate, both passing through gap junctions, have been found to maintain meiotic arrest [186,187]. A third aspirant growth messenger is $\mathrm{IP}_{3}$, a key player in calcium signalling and therefore a determinant of cell cycling [188]. In this context, Stains and Civitelli showed the existence of connexin response element (CXRE) in the promoter region of the rat osteocalcin gene, which is controlled by Sp1 transcription factors. Upon extracellular growth stimulation ("gap junction-independent primary response"), an unknown second messenger, possibly $\mathrm{IP}_{3}$, propagates by means of gap junctions ("gap junction-dependent primary response") and subsequently triggers the ERK and phosphoinositide 3-kinase/protein kinase B signalling cascade. Activated ERK then translocates to the nucleus, where it phosphorylates Sp1. The latter binds to the CXRE module, resulting in osteocalcin gene transcription and thus bone formation [189-191].

4.2.1.2. Hemichannel-dependent mechanisms. As also holds true for their full channel cognates, inhibition studies frequently point to roles for connexons in cell cycle management. The Cx43 hemichannel inhibitor ${ }^{43} \mathrm{Gap} 27$, that mimics an amino acid sequence in the second extracellular loop of the $\mathrm{Cx} 43$ protein, reduces proliferation of activated human $\mathrm{T}$ cells, as evidenced by an increased amount of G0/G1 phase cells and a decreased S cell population number [87]. By contrast, ${ }^{43}$ Gap27 lowers dye uptake through $\mathrm{Cx} 43$ hemichannels which coincides with enhanced wound healing and proliferation of human keratinocytes and skin fibroblasts in vitro and ex vivo [192]. Such findings are further substantiated by applying genetic strategies. Artificial introduction of the Cx32 gene or the Cx43 gene into rat pheochromocytoma cells and subsequent exposure to nerve growth factor results in enhanced neurite outgrowth. However, this does not depend on the establishment of GJIC, but relies on extracellular ATP release through connexin hemichannels [193]. Upon transfection of mutated Cx30 in human cervical cancer cells and Xenopus laevis oocytes, the ability to form intercellular channels is retained, but leaky connexin hemichannels are observed. Cx30 mutations are known to be involved in a genetic disorder called hidrotic ectodermal dysplasia, also known as the Clouston syndrome, which is characterized by palmoplantar hyperkeratosis. It is believed that increased ATP release through leaky $\mathrm{C} \times 30$ hemichannels interferes with paracrine signalling in the epidermis, ultimately leading to keratinocyte hyperproliferation [194]. From such studies, it is clear that connexin hemichannels may fulfil crucial and quite specific functions in cell cycling. In the developing neocortex of rat, spontaneous intercellular calcium waves propagate through radial glial cells and modulate cell proliferation. These calcium waves, involving the release of calcium from $\mathrm{IP}_{3}$-sensitive intracellular stores, are mediated by extracellular ATP and are critical to drive G1 phase cells into the S phase. Connexin hemichannels are opened upon initiation of DNA synthesis, followed by the extracellular release of ATP and the increase in the intracellular calcium concentration in neighbouring radial glial cells that linger in the G1/S transition [195]. Spontaneous rise in intracellular calcium concentration also triggers $\mathrm{Cx} 43$ hemichannel opening in developing retinal epithelium cells. Released ATP binds to purinergic receptors of adjacent retinal pigment epithelium cells and causes an increase in the intracellular calcium concentration and progenitor cells in the neural retina, resulting in increased cell proliferation [196]. Furthermore, hemichannels and gap junctions composed of $\mathrm{Cx} 43$ modulate the rate of the interkinetic nuclear movement (i.e. the back-and-forth migration of nuclei across the proliferative zone during the G1 phase, the G2 phase and the $\mathrm{M}$ phase of the cell cycle) in retinal progenitor cells, which is an essential determinant of cell cycle duration [197]. Recently, an identical role for both channel types has been described during interkinetic nuclear migration in murine forebrain precursors, whereby it was found that blocking $\mathrm{Cx} 43$ channels leads to phosphorylation of the cell division control protein 42 [198]. Besides ATP, hemichannels also control the extracellular liberation of $\mathrm{NAD}^{+}$, known to influence proliferative activity. In fact, released $\mathrm{NAD}^{+}$is processed by the ectoenzyme cluster of differentiation 38 (CD38), an integral membrane protein possessing an active extracellular site, yielding cyclic ADP-ribose (cADPr). cADPr reenters the cell or moves to another cell and acts as a second messenger by inducing calcium release from the endoplasmic reticulum. A similar pathway is equally observed within individual cells. In this case, both CD38 and connexons are located in intracellular vesicles. Upon hemichannel-mediated introduction of $\mathrm{NAD}^{+}, \mathrm{cADPr}$ is produced in the vesicle lumen and becomes released in the cytosol via $\mathrm{CD} 38$, again altering the calcium concentration [199-203]. Franco and co-workers [201] showed that an increase of the cytosolic calcium concentration, initiated by either enhanced exchange of $\mathrm{NAD}^{+}$(Cx43 hemichannelmediated) and cADPr, or an extracellular exchange of both signalling metabolites, results in increased cell proliferation in mouse fibroblast cultures via shortening of the $\mathrm{S}$ phase.

\subsubsection{Mechanisms not related to connexin channel formation}

4.2.2.1. Modulation of the expression of cell growth regulators. While genetically interfering with connexin expression, it has been regularly observed that effects on cell growth can occur independently of changes in channel activity, in casu GJIC [112,114,118,121,122,142$144,148,156,160,204-215]$. In consistence with these observations is the fact that connexin proteins, as single entities, can affect the production and/or activity of cell growth regulators, including p $27^{\mathrm{Kip} 1}$, cyclin A, cyclin D1, cyclin D2, cdk5, cdk6, ERK1/2, signal transducer and activator of transcription protein 3, Src, human EGF receptor 2, FGF1 and FGF receptor 3 which may [122,142-144,152,155,169,216-221] or may not $[122,142-144,148,156,160,209,212,222,223]$ be related to the presence of gap junction activity. A most representative study in this respect includes the works of Zhang and colleagues. They showed that forced expression of $\mathrm{Cx} 43$ causes a G1/S cell cycle arrest in human osteosarcoma cells, which is associated with accumulation of hypophosphorylated retinoblastoma protein, decreases in cdk2 and cdk4 activities and increased p2 $27^{\mathrm{Kip} 1}$ expression. The latter is, at least in part, a result of the reintroduction of gap junctions, which allow the intercellular flux of cAMP, being an enhancer of p2 $7^{\text {Kip } 1}$ synthesis. Simultaneously, $\mathrm{Cx} 43$ promotes the degradation of the $\mathrm{S}$ phase kinaseassociated protein 2 , a protein that is involved in $\mathrm{p} 27^{\mathrm{Kip} 1}$ ubiquitination. The overall interplay between these GJIC-dependent and GJIC-independent mechanisms results in the accumulation of $\mathrm{p} 27^{\mathrm{Kip} 1}$ and thus a proliferative block [142-144]. The precise mechanisms beyond the gap junction-unrelated actions of connexins on the expression of cell growth regulators remain, however, obscure. It has been suggested that 
connexins can directly affect gene transcription. Connexins, or at least specific parts of these molecules, have been reported to reside in the cell nucleus. Upon its forced expression in human cervical cancer cells [206], human embryonic kidney cells [206] and mouse neuroblastoma cells [215], the C-terminal tail portion of the Cx43 molecule becomes diffusely located in the cell, including the nuclear compartment, which could underlie the subsequent inhibition of cell growth. Likewise, human cervical cancer cells transfected with mutated $\mathrm{Cx} 43$, bearing point mutations in the second extracellular loop region, do not display GJIC because of aberrant cytosolic localization of $\mathrm{Cx} 43$, though cell growth is still suppressed [112]. Omori and Yamaski [115], however, found that mutants of both $\mathrm{Cx} 32$ and $\mathrm{Cx} 43$, lacking their C-terminal tail, but not their wild-type counterparts inhibit cell proliferation in this same cell type, suggesting that structural regions other than the Cterminal portion are critical for connexin-mediated control of cell growth. Alternatively, the connection between connexins and the production of cell growth regulatory substances could also be more indirect and may arise from the interaction between connexins and a number of key homeostasis regulators. This set of mechanisms will be addressed in the following paragraph.

\subsubsection{Interaction with cell growth regulators}

4.2.2.2.1. $\beta$-Catenin. Two pools of $\beta$-catenin are found in the cell, namely at the cell plasma membrane surface, where it serves as a building stone for adherens junctions, and in the cytosol, where it functions as a regulatory component of the canonical Wingless-Int (Wnt) signalling pathway. In the absence of Wnt signals, being secreted glycoproteins, cytosolic ß-catenin forms a complex with the adenomatous polyposis coli tumor suppressor, axin and glycogen synthase kinase-3ß. This complex phosphorylates $ß$-catenin, serving as a trigger to induce its degradation. Upon the binding of a Wnt ligand to its receptor at the cell plasma membrane surface, the degradation complex becomes destabilized, resulting in cytosolic ß-catenin accumulation. The latter then moves to the nucleus, where it binds to transcription factors belonging to the family of the T cell factors/lymphoid enhancer factors. This complex subsequently activates the transcription of a number of genes that code for G1/S cell cycle regulators, such as cyclin D1 and c-myc [224-228]. Furthermore, Wnt signalling also controls the G2/M transition of the cell cycle [229]. It has been reported that ß-catenin interacts with $\mathrm{Cx} 43$ at cell-cell contact areas, and by doing so, Cx43 reduces the total amount of $ß$-catenin that is available for Wnt signalling, thus leading to inhibition of cell proliferation [230,231]. Interestingly, the Cx43 gene itself has been identified as a downstream target for Wnt signalling, which suggests that Cx43 can regulate its own production [230,232]. In fact, activation of the Wnt signalling cascade by a number of stimuli resulted in increased $\mathrm{Cx} 43$ expression and in some cases, this was associated with enhanced GJIC and proliferative potential $[230,232-242]$.

4.2.2.2.2. E-cadherin. Despite the acknowledged colocalization of gap junctions with adherens junctions and in contrast to ß-catenin, the direct physical interaction between connexins and cadherins still is a matter of debate $[14,243-246]$. Nevertheless, intimate crosstalk between both cell junction types is critical for their proper formation, localization and function [236,247-256]. In regenerating mouse hepatocytes, for instance, the assembly of adherens junctions composed of E-cadherin, and thus the presence of cell adhesion, is indispensable for the establishment of $\mathrm{Cx} 32$-based gap junctions [257]. Vice versa, transfection of human liver cancer cells with the Cx26 gene reduces cell growth, which is associated with induced Ecadherin expression and thereby the formation of cell adhesion complexes $[138,139]$. In a similar way, genetic introduction of $\mathrm{Cx} 43$ in human lung cancer cells activates E-cadherin production and causes a G1/S cell cycle arrest [258]. In addition, overexpression of N-cadherin and $\mathrm{Cx} 43$ in human embryonic kidney cells synergistically suppresses cell proliferation by prolonging the G2/M cell cycle transition. This is accompanied by elevated expression of $\mathrm{p} 21^{\mathrm{Cip} 1}$, which relies on Wnt signalling, and a concomitant decline in cdk1 activity [231].
4.2.2.2.3. Nephroblastoma overexpressed protein. Ectopic expression of Cx43 in glioma cells increases GJIC and decreases cell growth in vitro and in vivo, coinciding with elevated expression of the cysteine rich 61 (Cyr61) protein and the nephroblastoma overexpressed (NOV) protein. The latter hereby colocalizes with $\mathrm{Cx} 43$ gap junction plaques at the cell plasma membrane surface [259-262]. It has indeed been shown that NOV interacts with $\mathrm{Cx} 43$, but not with other connexins, including $\mathrm{Cx} 32$ and $\mathrm{Cx} 40$, in glioma cells and choriocarcinoma cells [263-265]. NOV is a member of the CCN family, which is an acronym for Cyr61, connective tissue growth factor (CTGF) and NOV. CCN proteins are multimodular regulators known to play roles in a number of biological processes [266]. NOV itself is involved in cell cycle control and inhibits proliferation. It is believed that $\mathrm{Cx} 43$ is able to regulate cell growth by increasing NOV production, the concomitant shift of NOV localization from the nucleus to the cell plasma membrane surface and the direct binding of NOV to Cx43 [263-265].

4.2.2.2.4. Zonula occludens 1-associated nucleic acid binding protein. $\mathrm{Cx} 30, \mathrm{Cx} 32, \mathrm{Cx} 43$ and $\mathrm{Cx} 47$ all colocalize with ZO-1-associated nucleic acid binding protein (ZONAB) in rat brain [267,268]. ZONAB is a transcription factor that binds to inverted CCAAT-box sequences, found in the promoter region of genes coding for several cell growth regulators, including cyclin D1 and the proliferating cell nuclear antigen [269]. As the name suggests, ZONAB interacts with zonula occludens 1 (ZO-1), being a tight junction component. Interaction between ZONAB and ZO-1, and thus cell growth control, occurs in a cell density-dependent manner. Indeed, cells grown at low density display low ZONAB-ZO-1 interaction and a high proliferative potential. In these cells, ZONAB accumulates in the nucleus, where it represses the gene transcription of human EGF receptor 2, a receptor tyrosine kinase involved in cell growth $[270,271]$. ZONAB also binds to a number of other proteins, which may directly or indirectly modulate its transcriptional activity in relation to cell proliferation, including cdk4 [270,271], ras-related protein [272], heath shock protein 4A [273], symplekin [274,275] and the guanine nucleotide exchange factor H1/Lbc's first cousin [276].

4.2.2.2.5. Zonula occludens proteins. Apart from the indirect contact via ZONAB, ZO-1 as well as ZO-2 also directly interact with $\mathrm{Cx} 43$. This process is subject to cell cycle phase-specific control. Thus, $\mathrm{Cx} 43$ has a strong binding preference for ZO-1 during the G0 phase, whereas Cx43-ZO-2 interaction occurs equally during the G0 phase and the $S$ phase in rat kidney epithelial cells [277]. Similar to ZO-1, ZO-2 binds to transcription factors, in casu c-jun, c-fos and CCAAT enhancer binding protein [278] and thereby shuttles between the cell periphery and the nucleus [279-281]. As such, ZO-2 was found to downregulate cyclin D1 gene transcription [281,282], to increase cyclin D1 protein degradation [281] and ultimately to inhibit cell cycling at the G0/G1 transition [281].

4.2.2.2.6. Discs-large homolog 1 protein. In hepatocytes, Cx32 interacts with the scaffolding protein Dlgh1 (discs-large homolog 1). Dlgh1 acts as a tumor suppressor protein and its presence at the cell plasma membrane surface, bound to $\mathrm{Cx} 32$, is associated with a cell cycle block at the G0/G1 transition. Upon its release, occurring following downregulation of Cx32 expression, Dlgh1 translocates to the cell nucleus, where its actions lead to increased proliferative activity. Therefore, maintaining Dlgh1 at the cell plasma membrane surface may be a regulatory mechanism by which $\mathrm{Cx} 32$ controls hepatocyte proliferation [283].

4.2.2.2.7. Involvement of pannexin-related signalling. Another level of promiscuity in the complicated relationship between connexin-related signalling and cell cycling is formed by pannexins. This recently discovered protein family yet consists of three members (Panx1-3) in rodents and man. Despite the lack of sequence homology between connexins and pannexins, they share a similar topology and also display cell-specific expression patterns. Pannexins, however, tend to gather as hexameric hemichannels, rather than in a gap junction configuration. Like their connexin counterparts, pannexin hemichannels allow the passive 
flux of small molecules, such as ATP, between the cytosol and the extracellular environment. The permeability of pannexin hemichannels can be altered by a number of stimuli, including changes in intracellular calcium and hydrogen concentration, and membrane potentials $[19,284,285]$. Several lines of evidence suggest a role for pannexins in cell proliferation. Following induced expression in rat glioma cells, Panx1 becomes located in the Golgi apparatus and at the cell plasma membrane surface. This results in increased GJIC, reduced proliferative activity in vitro and suppressed tumor growth in vivo [286]. In a similar way, Panx2 behaves as a negative growth regulator upon exogenous introduction into these cells, both in vitro and in vivo. Panx2 is hereby predominantly localized in the cytoplasm and does not affect GJIC or the production of Panx1 and Cx43 [287]. Pannexins also affect proliferative events as hemichannel entities, such as during adaptive immune response. Upon $\mathrm{T}$ cell activation by binding to an antigen presenting cell, ATP becomes released through Panx1 hemichannels in a calcium-dependent manner. Released ATP from $\mathrm{T}$ cells not only binds to purinergic receptors on antigen presenting cells but also to own purinergic receptors. The latter activates a MAPK signalling cascade and serves as an autocrine costimulus for T cell proliferation [288]. In a more pathological context, Panx1 hemichannels are involved in cardiac fibrosis induced by pressure overload. Upon mechanical stress, ATP and uridine diphosphate are released from cardiac myocytes via Panx1 hemichannels, leading to stimulation of purinergic receptors that subsequently activate guanine nucleotide-binding proteins. Consequently, the expression of a number of fibrogenic factors becomes induced in cardiomyocytes, including trans- forming growth factor- $\beta$ and connective tissue growth factor. These fibrogenic factors evoke activation and proliferation of cardiac fibroblasts in a paracrine manner [289]. Recently, Iwamoto and colleagues showed that Panx3 functions as a hemichannel following transfection in murine chondrocytic cells, whereby intracellular ATP and cAMP levels become reduced. This impedes phosphorylation and thus activation of the cAMP response element binding transcription factor. The latter is a downstream effector of the parathyroid hormone/protein kinase A/cAMP signalling cascade that regulates cell growth in chondrocytes. As a result of its inactivation, the cAMP response element binding transcription factor can no longer bind to its target genes, including the cyclin D1 and cyclin A genes, and cell proliferation becomes suppressed [290].

\section{Conclusions and perspectives}

Tissue homeostasis basically relies on the critical balance between cell growth and cell death and is controlled by a myriad of signalling networks. As outlined in this paper, numerous studies have demonstrated dynamic changes in connexin-related signalling throughout this process, and more specifically in cell proliferation. Although it has been suggested that these modifications are merely irrelevant side effects of cell cycling $[40,41,172]$, most investigators believe that a straightforward causal link exists between connexin-related signalling and cell proliferation. As a matter of fact, connexins and their channels actively control cell proliferation at three communicative levels. At the intercellular level, GIIC foresees the direct exchange of cell growth regulators between

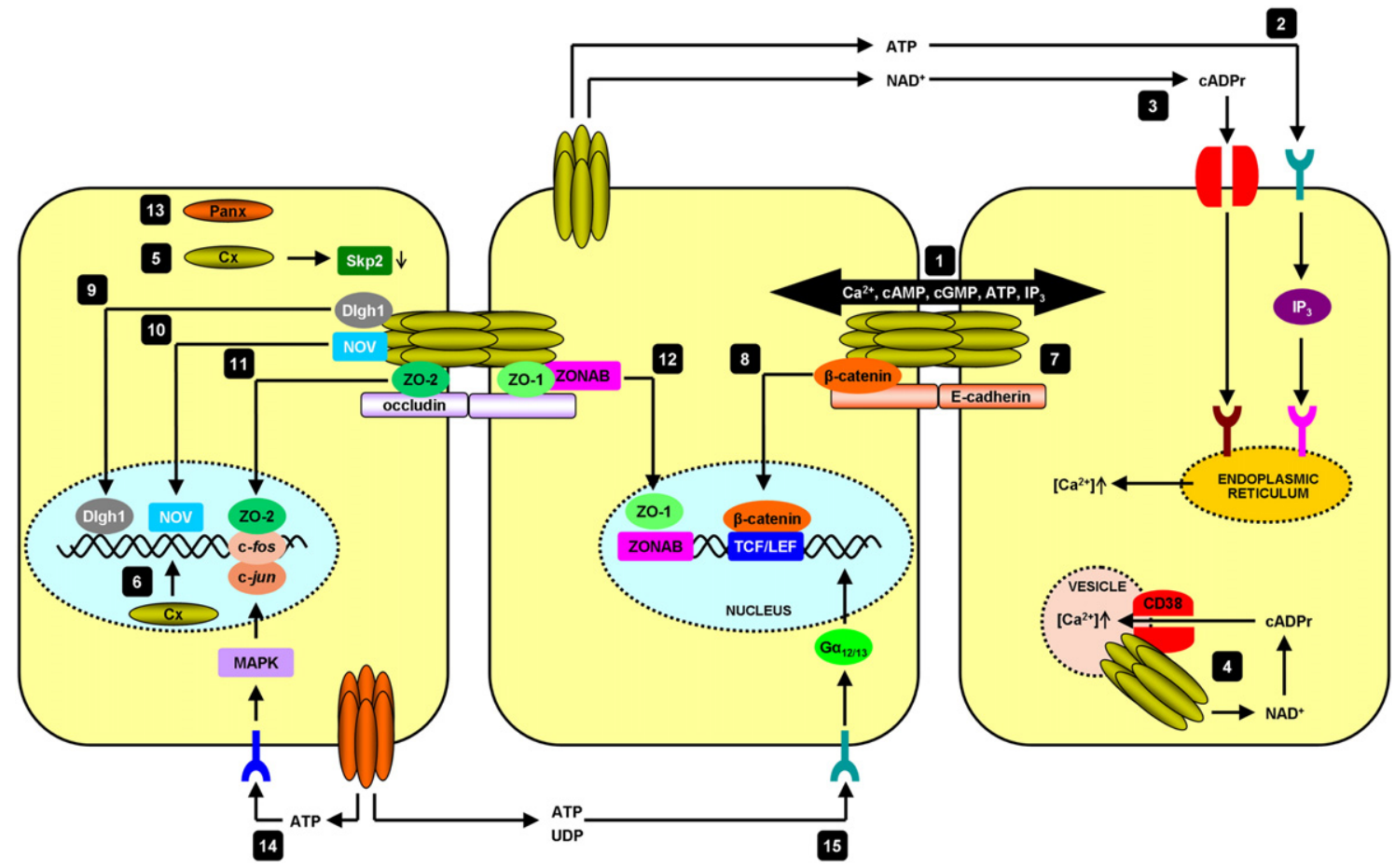

Fig. 2. Connexin-related signalling in the control of cell proliferation. A number of connexin-akin mechanisms are involved in cell cycle regulation, comprising gap junctions (1), connexin hemichannels (2-4), connexins (5-12) and pannexins (13-16). Gap junctions mediate the direct intercellular exchange of positive and negative cell growth regulators (1). Hemichannels allow the extracellular liberation of ATP $(2)$ and $\operatorname{NAD}^{+}(3)$. The former interacts with purinergic receptors of adjacent cells, which triggers production of IP. The latter is processed to cADPr and subsequently taken up by the cell through the ectoenzyme $\mathrm{CD} 38$. Both $\mathrm{IP}_{3}$ and cADPr bind to their corresponding receptors in the endoplasmic reticulum, leading to release of calcium in the cytosol. A similar NAD ${ }^{+}$/CADPr pathway is observed intracellularly, whereby both CD38 and connexin hemichannels are located in vesicles (4). Connexin proteins as such, particularly Cx43, can promote the degradation of the Skp2 protein (5) or can directly interfere with the gene expression of cell growth regulators in the nucleus (6). Connexins colocalize with cadherins that maintain cell adhesion, which in turn favours cell growth arrest (7). Cx43 also interacts with another adherens junction building stone, namely ß-catenin, being a critical component of the Wnt signalling cascade, known to affect cell cycling (8). Cx32 and Cx43 bind to Dlgh1 (9) and NOV (10), respectively, that both influence cell growth. Connexins (i.e. Cx43) bind to the tight junction components ZO-2 (11) and ZO-1 (12) that interact with transcription factors, such as AP-1 (c-jun/c-fos) and ZONAB, respectively, known to control the gene transcription of cell growth regulators. Panx1 and Panx2 present at the cell plasma membrane surface, the Golgi apparatus or in the cytosol suppress cell proliferation (13). ATP and UDP can be extracellularly released through Panx1 hemichannels that, upon binding to purinergic receptors at the cell plasma membrane surface, trigger a MAPK signalling cascade (14) or G $\alpha_{12 / 13}$ proteins (15), ultimately resulting in the onset of cell growth. (AP-1, activator protein 1; ATP, adenosine triphosphate; $\mathrm{Ca}^{2+}$, calcium; cADPr, cyclic adenosine diphosphate ribose; Cx, connexin; Dlgh1, discs-large homolog 1; IP, inositol trisphosphate; MAPK, mitogenactivated protein kinase; $\mathrm{NAD}^{+}$, nicotinamide adenine dinucleotide; NOV, nephroblastoma overexpressed; Panx, pannexin; Skp2, S phase kinase-associated protein 2; UDP, uridine diphosphate; ZO-1/2, zonula occludens 1/2; ZONAB, ZO-1-associated nucleic acid binding protein). 
adjacent cells. At the extracellular level, connexin hemichannels allow the paracrine release of homeostasis regulatory proteins. At the intracellular level, connexin proteins can directly or indirectly affect the production of cell cycle regulators or can act as a cellular signalling reservoir by reversibly interacting with these substances. In recent years, pannexins have also joined in as regulators of the homeostatic balance, which they can affect as either single units or as channel entities (Fig. 2). Although exceptions exist, it could be stated that gap junctions and connexin/ pannexin protein actions are generally associated with suppression of proliferative activity, whereas hemichannels rather promote cell cycling. This suggests differential regulation depending on the connexin/ pannexin assembly status, a principle that has already been elegantly demonstrated in the case of phosphorylation of $\mathrm{Cx} 43$ [106,107]. It is tempting to speculate that other posttranslational modifications might also play a role in this process. $\mathrm{Cx} 26$, for instance, was recently found to be a substrate for acetylation, hydroxylation, $\gamma$-carboxyglutamation and methylation [291]. Considerable differences in this respect equally exist between the two types of channel-forming proteins, since pannexins, unlike connexins, can be glycosylated [292,293]. The many connexinbinding proteins, the so-called gap junction proteome [14], that still continue to be discovered are likely to be involved in the distinct regulation of connexin/pannexin channels as well. Collectively, such actions could alter channel permeability which in turn might allow finetuned selection of cell growth messenger traffic. A number of other mechanisms that might underlie connexin-related control of cell proliferation also await exploitation. In this respect, microRNA species have recently entered the connexin arena at the posttranscriptional platform [26-31], though its relevance to cell cycle management has not yet been documented. Inversely, the intrinsic functions of connexin proteins in the control of cell cycle regulator gene transcription also deserve further scrutiny. It will be of the utmost importance to establish the relative importance of each of these mechanisms under physiological and pathological circumstances, as thus far the majority of studies in this field have used cancerous or transformed cells, both in in vivo and in vitro settings. An equally important and even more fundamental challenge concerns the elucidation of the exact contribution of gap junctions and hemichannels composed of either connexins or pannexins to cell proliferation. This research is currently hampered by the ubiquitous lack of appropriate testing approaches that enable unequivocal discrimination between the different channel types and its constituents, especially in an in vivo environment [21,294]. Thus, many acknowledged gap junction inhibitors, including carbenoxolone, also inhibit connexons and pannexin channels [19]. Such constraints similarly hold true for certain connexin mimetic peptides that are claimed to be specific connexin hemichannel inhibitors, but which additionally suppress GJIC depending on the time frame of application [295]. It can be anticipated that upon introduction of appropriate experimental tools, more insight will be gained into the molecular mechanisms that drive connexinrelated signalling in cell cycle control.

\section{Acknowledgements}

This work was financially supported by the grants of the Research Council of the Vrije Universiteit Brussel (OZR-VUB), the Fund for Scientific Research Flanders (FWO-Vlaanderen) and the European Union (FP6 project carcinoGENOMICS).

\section{References}

[1] M. Malumbres, M. Barbacid, Cell cycle, CDKs and cancer: a changing paradigm, Nat. Rev. Cancer 9 (2009) 153-166.

[2] M. Fussenegger, J.E. Bailey, Molecular regulation of cell-cycle progression and apoptosis in mammalian cells: implications for biotechnology, Biotechnol. Prog. 14 (1998) 807-833.

[3] R. Suryadinata, M. Sadowski, B. Sarcevic, Control of cell cycle progression by phosphorylation of cyclin-dependent kinase (CDK) substrates, Biosci. Rep. 30 (2010) 243-255.
[4] S. van den Heuvel, Cell-cycle regulation, WormBook (2005) 1-16.

[5] S. Meloche, J. Pouyssegur, The ERK1/2 mitogen-activated protein kinase pathway as a master regulator of the G1- to S-phase transition, Oncogene 26 (2007) 3227-3239.

[6] M. Vinken, E. De Rop, E. Decrock, E. De Vuyst, L. Leybaert, T. Vanhaecke, V. Rogiers, Epigenetic regulation of gap junctional intercellular communication: more than a way to keep cells quiet? Biochim. Biophys. Acta 1795 (2009) 53-61.

[7] M. Vinken, T. Doktorova, E. Decrock, L. Leybaert, T. Vanhaecke, V. Rogiers, Gap junctional intercellular communication as a target for liver toxicity and carcinogenicity, Crit. Rev. Biochem. Mol. Biol. 44 (2009) 201-222.

[8] M. Vinken, T. Henkens, E. De Rop, J. Fraczek, T. Vanhaecke, V. Rogiers, Biology and pathobiology of gap junctional channels in hepatocytes, Hepatology 47 (2008) 1077-1088.

[9] M. Vinken, P. Papeleu, S. Snykers, E. De Rop, T. Henkens, J.K. Chipman, V. Rogiers, T. Vanhaecke, Involvement of cell junctions in hepatocyte culture functionality, Crit. Rev. Toxicol. 36 (2006) 299-318.

[10] M. Vinken, T. Vanhaecke, P. Papeleu, S. Snykers, T. Henkens, V. Rogiers, Connexins and their channels in cell growth and cell death, Cell. Signal. 18 (2006) 592-600.

[11] H.A. Dbouk, R.M. Mroue, M.E. El-Sabban, R.S. Talhouk, Connexins: a myriad of functions extending beyond assembly of gap junction channels, Cell. Commun. Signal 7 (2009) 4.

[12] D.A. Goodenough, D.L. Paul, Gap junctions, Cold Spring Harbor Perspect. Biol. 1 (2009) a002576.

[13] M. Rackauskas, V. Neverauskas, V.A. Skeberdis, Diversity and properties of connexin gap junction channels, Medicina 46 (2010) 1-12.

[14] D.W. Laird, The gap junction proteome and its relationship to disease, Trends Cell Biol. 20 (2010) 92-101.

[15] D.B. Alexander, G.S. Goldberg, Transfer of biologically important molecules between cells through gap junction channels, Curr. Med. Chem. 10 (2003) 2045-2058.

[16] E. Decrock, M. Vinken, E. De Vuyst, D.V. Krysko, K. D'Herde, T. Vanhaecke, P. Vandenabeele, V. Rogiers, L. Leybaert, Connexin-related signaling in cell death: to live or let die? Cell Death Differ. 16 (2009) 524-536.

[17] G.T. Cottrell, J.M. Burt, Functional consequences of heterogeneous gap junction channel formation and its influence in health and disease, Biochim. Biophys. Acta 1711 (2005) 126-141.

[18] G.S. Goldberg, A.P. Moreno, P.D. Lampe, Gap junctions between cells expressing connexin 43 or 32 show inverse permselectivity to adenosine and ATP, J. Biol. Chem. 277 (2002) 36725-36730.

[19] C. D'Hondt, R. Ponsaerts, H. De Smedt, G. Bultynck, B. Himpens, Pannexins, distant relatives of the connexin family with specific cellular functions? Bioessays 31 (2009) 953-974.

[20] W.H. Evans, E. De Vuyst, L. Leybaert, The gap junction cellular internet: connexin hemichannels enter the signalling limelight, Biochem. J. 397 (2006) 1-14.

[21] K.A. Schalper, N. Palacios-Prado, J.A. Orellana, J.C. Saez, Currently used methods for identification and characterization of hemichannels, Cell Commun. Adhes. 15 (2008) 207-218.

[22] A.P. Moreno, A.F. Lau, Gap junction channel gating modulated through protein phosphorylation, Prog. Biophys. Mol. Biol. 94 (2007) 107-119.

[23] J.L. Solan, P.D. Lampe, Connexin43 phosphorylation: structural changes and biological effects, Biochem. J. 419 (2009) 261-272.

[24] G. Sohl, K. Willecke, Gap junctions and the connexin protein family, Cardiovasc. Res. 62 (2004) 228-232.

[25] M. Oyamada, Y. Oyamada, T. Takamatsu, Regulation of connexin expression, Biochim. Biophys. Acta 1719 (2005) 6-23.

[26] C. Anderson, H. Catoe, R. Werner, MIR-206 regulates connexin43 expression during skeletal muscle development, Nucleic Acids Res. 34 (2006) 5863-5871.

[27] T.E. Callis, K. Pandya, H.Y. Seok, R.H. Tang, M. Tatsuguchi, Z.P. Huang, J.F. Chen, Z. Deng, B. Gunn, J. Shumate, M.S. Willis, C.H. Selzman, D.Z. Wang, MicroRNA-208a is a regulator of cardiac hypertrophy and conduction in mice, J. Clin. Invest. 119 (2009) 2772-2786.

[28] H. Inose, H. Ochi, A. Kimura, K. Fujita, R. Xu, S. Sato, M. Iwasaki, S. Sunamura, Y. Takeuchi, S. Fukumoto, K. Saito, T. Nakamura, H. Siomi, H. Ito, Y. Arai, K.I. Shinomiya, S. Takeda, A microRNA regulatory mechanism of osteoblast differentiation, Proc. Natl Acad. Sci. USA 106 (2009) 20794-20799.

[29] H.K. Kim, Y.S. Lee, U. Sivaprasad, A. Malhotra, A. Dutta, Muscle-specific microRNA miR-206 promotes muscle differentiation, J. Cell Biol. 174 (2006) 677-687.

[30] Y. Lu, Y. Zhang, H. Shan, Z. Pan, X. Li, B. Li, C. Xu, B. Zhang, F. Zhang, D. Dong, W. Song, G. Qiao, B. Yang, MicroRNA-1 downregulation by propranolol in a rat model of myocardial infarction: a new mechanism for ischaemic cardioprotection, Cardiovasc. Res. 84 (2009) 434-441.

[31] B. Yang, H. Lin, J. Xiao, Y. Lu, X. Luo, B. Li, Y. Zhang, C. Xu, Y. Bai, H. Wang, G. Chen, Z. Wang, The muscle-specific microRNA miR-1 regulates cardiac arrhythmogenic potential by targeting GJA1 and KCNJ2, Nat. Med. 13 (2007) 486-491.

[32] H. Goodall, B. Maro, Major loss of junctional coupling during mitosis in early mouse embryos, J. Cell Biol. 102 (1986) 568-575.

[33] P.D. Lampe, W.E. Kurata, B.J. Warn-Cramer, A.F. Lau, Formation of a distinct connexin43 phosphoisoform in mitotic cells is dependent upon p34cdc2 kinase, J. Cell Sci. 111 (1998) 833-841.

[34] L.S. Stein, J. Boonstra, R.C. Burghardt, Reduced cell-cell communication between mitotic and nonmitotic coupled cells, Exp. Cell Res. 198 (1992) 1-7.

[35] J.W. Su, L.G. Tertoolen, S.W. de Laat, W.J. Hage, A.J. Durston, Intercellular communication is cell cycle modulated during early Xenopus laevis development, J. Cell Biol. 110 (1990) 115-121.

[36] H. Xie, D.W. Laird, T.H. Chang, V.W. Hu, A mitosis-specific phosphorylation of the gap junction protein connexin43 in human vascular cells: biochemical characterization and localization, J. Cell Biol. 137 (1997) 203-210. 
[37] P. O'Lague, H. Dalen, H. Rubin, C. Tobias, Electrical coupling: low resistance junctions between mitotic and interphase fibroblasts in tissue culture, Science 170 (1970) 464-466.

[38] G.K. Michalopoulos, M. DeFrances, Liver regeneration, Adv. Biochem. Eng. Biotechnol. 93 (2005) 101-134.

[39] R. Taub, Liver regeneration: from myth to mechanism, Nat. Rev. Mol. Cell Biol. 5 (2004) 836-847.

[40] R. Dermietzel, S.B. Yancey, O. Traub, K. Willecke, J.P. Revel, Major loss of the 28-kD protein of gap junction in proliferating hepatocytes, J. Cell Biol. 105 (1987) 1925-1934.

[41] K.E. Fladmark, B.T. Gjertsen, A. Molven, G. Mellgren, O.K. Vintermyr, S.O. Doskeland, Gap junctions and growth control in liver regeneration and in isolated rat hepatocytes, Hepatology 25 (1997) 847-855.

[42] T. Kojima, T. Yamamoto, M. Lan, M. Murata, K. Takano, M. Go, S. Ichimiya, H. Chiba, N. Sawada, Inhibition of MAP kinase activity moderates changes in expression and function of Cx32 but not claudin-1 during DNA synthesis in primary cultures of rat hepatocytes, Med. Electron Microsc. 37 (2004) 101-113.

[43] T. Kojima, T. Yamamoto, M. Murata, M. Lan, K. Takano, M. Go, S. Ichimiya, H. Chiba, N. Sawada, Role of the p38 MAP-kinase signaling pathway for Cx32 and claudin-1 in the rat liver, Cell Commun. Adhes. 10 (2003) 437-443.

[44] T. Yamamoto, T. Kojima, M. Murata, K. Takano, M. Go, N. Hatakeyama, H. Chiba, N. Sawada, p38 MAP-kinase regulates function of gap and tight junctions during regeneration of rat hepatocytes, J. Hepatol. 42 (2005) 707-718.

[45] B.T. Kren, N.M. Kumar, S.Q. Wang, N.B. Gilula, C.J. Steer, Differential regulation of multiple gap junction transcripts and proteins during rat liver regeneration, J. Cell Biol. 123 (1993) 707-718.

[46] D.J. Meyer, S.B. Yancey, J.P. Revel, Intercellular communication in normal and regenerating rat liver: a quantitative analysis, J. Cell Biol. 91 (1981) 505-523.

[47] Y. Sugiyama, H. Ohta, Changes in density and distribution of gap junctions after partial hepatectomy: immunohistochemical and morphometric studies, Arch. Histol. Cytol. 53 (1990) 71-80.

[48] A. Temme, T. Ott, F. Dombrowski, K. Willecke, The extent of synchronous initiation and termination of DNA synthesis in regenerating mouse liver is dependent on connexin32 expressing gap junctions, J. Hepatol. 32 (2000) 627-635.

[49] A.G. Yee, J.P. Revel, Loss and reappearance of gap junctions in regenerating liver, J. Cell Biol. 78 (1978) 554-564.

[50] T. Miyashita, A. Takeda, M. Iwai, T. Shimazu, Single administration of hepatotoxic chemicals transiently decreases the gap-junction-protein levels of connexin 32 in rat liver, Eur. J. Biochem. 196 (1991) 37-42

[51] O. Traub, P.M. Druge, K. Willecke, Degradation and resynthesis of gap junction protein in plasma membranes of regenerating liver after partial hepatectomy or cholestasis, Proc. Natl Acad. Sci. USA 80 (1983) 755-759.

[52] H. Li, X. Chen, F. Zhang, J. Ma, C. Xu, Expression patterns of the cell junctionassociated genes during rat liver regeneration, J. Genet. Genomics 34 (2007) 892-908.

[53] S. Koenig P. Krause, B. Drabent, I. Schaeffner, B. Christ, P. Schwartz, K. UnthanFechner, I. Probst, The expression of mesenchymal, neural and haematopoietic stem cell markers in adult hepatocytes proliferating in vitro, J. Hepatol. 44 (2006) 1115-1124.

[54] T. Kojima, M. Yamamoto, C. Mochizuki, T. Mitaka, N. Sawada, Y. Mochizuki, Different changes in expression and function of connexin 26 and connexin 32 during DNA synthesis and redifferentiation in primary rat hepatocytes using a DMSO culture system, Hepatology 26 (1997) 585-597.

[55] A. Trovato-Salinaro, N. Belluardo, M. Frinchi, J. von Maltzahn, K. Willecke, D.F. Condorelli, G. Mudo, Regulation of connexin gene expression during skeletal muscle regeneration in the adult rat, Am. J. Physiol. Cell Physiol. 296 (2009) C593-C606.

[56] A. Gorbe, D.L. Becker, L. Dux, L. Krenacs, T. Krenacs, In differentiating prefusion myoblasts connexin43 gap junction coupling is upregulated before myoblast alignment then reduced in post-mitotic cells, Histochem. Cell Biol. 125 (2006) 705-716.

[57] A. Gorbe, D.L. Becker, L. Dux, E. Stelkovics, L. Krenacs, E. Bagdi, T. Krenacs, Transient upregulation of connexin43 gap junctions and synchronized cell cycle control precede myoblast fusion in regenerating skeletal muscle in vivo, Histochem. Cell Biol. 123 (2005) 573-583.

[58] R.E. Gordon, B.P. Lane, M. Marin, Regeneration of rat tracheal epithelium: changes in gap junctions during specific phases of the cell cycle, Exp. Lung Res. 3 (1982) 47-56.

[59] S.W. Lee, C. Tomasetto, D. Paul, K. Keyomarsi, R. Sager, Transcriptional downregulation of gap-junction proteins blocks junctional communication in human mammary tumor cell lines, J. Cell Biol. 118 (1992) 1213-1221.

[60] K. Bittman, D.F. Owens, A.R. Kriegstein, J.J. LoTurco, Cell coupling and uncoupling in the ventricular zone of developing neocortex, J. Neurosci. 17 (1997) 7037-7044.

[61] K.S. Bittman, J.J. LoTurco, Differential regulation of connexin 26 and 43 in murine neocortical precursors, Cereb. Cortex 9 (1999) 188-195.

[62] M.R. Wilson, T.W. Close, J.E. Trosko, Cell population dynamics (apoptosis, mitosis, and cell-cell communication) during disruption of homeostasis, Exp. Cell Res. 254 (2000) 257-268.

[63] A. Cheng, H. Tang, J. Cai, M. Zhu, X. Zhang, M. Rao, M.P. Mattson, Gap junctional communication is required to maintain mouse cortical neural progenitor cells in a proliferative state, Dev. Biol. 272 (2004) 203-216.

[64] C. Haupt, O.W. Witte, C. Frahm, Up-regulation of Connexin43 in the glial scar following photothrombotic ischemic injury, Mol. Cell. Neurosci. 35 (2007) 89-99.

[65] G. Lemaitre, V. Sivan, J. Lamartine, J.M. Cosset, B. Cavelier-Balloy, D. Salomon, G. Waksman, M.T. Martin, Connexin 30, a new marker of hyperproliferative epidermis, Br. J. Dermatol. 155 (2006) 844-846.
[66] T. Matsushita, A. Rama, N. Charolidi, E. Dupont, N.J. Severs, Relationship of connexin43 expression to phenotypic modulation in cultured human aortic smooth muscle cells, Eur. J. Cell Biol. 86 (2007) 617-628.

67] T.I. Shakespeare, C. Sellitto, L. Li, C. Rubinos, X. Gong, M. Srinivas, T.W. White, Interaction between Connexin 50 and mitogen-activated protein kinase signaling in lens homeostasis, Mol. Biol. Cell 20 (2009) 2582-2592.

[68] T.W. White, Y. Gao, L. Li, C. Sellitto, M. Srinivas, Optimal lens epithelial cell proliferation is dependent on the connexin isoform providing gap junctional coupling, Invest. Ophthalmol Vis Sci. 48 (2007) 5630-5637.

[69] G.O. Edwards, S. Jondhale, T. Chen, J.K. Chipman, A quantitative inverse relationship between connexin32 expression and cell proliferation in a rat hepatoma cell line, Toxicology 253 (2008) 46-52.

70] F. Lu, J. Gao, R. Ogawa, H. Hyakusoku, Variations in gap junctional intercellular communication and connexin expression in fibroblasts derived from keloid and hypertrophic scars, Plast. Reconstr. Surg. 119 (2007) 844-851.

[71] F. Miragall, P. Albiez, H. Bartels, U. de Vries, R. Dermietzel, Expression of the gap junction protein connexin43 in the subependymal layer and the rostra migratory stream of the mouse: evidence for an inverse correlation between intensity of connexin 43 expression and cell proliferation activity, Cell Tissue Res. 287 (1997) 243-253.

[72] T. Saito, R. Tanaka, K. Wataba, R. Kudo, H. Yamasaki, Overexpression of estrogen receptor-alpha gene suppresses gap junctional intercellular communication in endometrial carcinoma cells, Oncogene 23 (2004) 1109-1116.

[73] Y. Shiba, Y. Sasaki, Y. Kanno, Inhibition of gap-junctional intercellular communication and enhanced binding of fibronectin-coated latex beads by stimulation of DNA synthesis in quiescent 3T3-L1 cells, J. Cell. Physiol. 145 (1990) 268-273.

[74] A. Trovato-Salinaro, E. Trovato-Salinaro, M. Failla, C. Mastruzzo, V. Tomaselli, E. Gili, N. Crimi, D.F. Condorelli, C. Vancheri, Altered intercellular communication in lung fibroblast cultures from patients with idiopathic pulmonary fibrosis, Respir. Res. 7 (2006) 122.

[75] I. Edry, S. Sela-Abramovich, N. Dekel, Meiotic arrest of oocytes depends on cell-to-cell communication in the ovarian follicle. Mol. Cell. Endocrinol. 252 (2006) 102-106.

[76] Q.Y. Sun, Y.L. Miao, H. Schatten, Towards a new understanding on the regulation of mammalian oocyte meiosis resumption, Cell Cycle 8 (2009) 2741-2747.

[77] E.K. Kim, E.J. Choi, Pathological roles of MAPK signaling pathways in human diseases, Biochim. Biophys. Acta 1802 (2010) 396-405.

[78] M. Krishna, H. Narang, The complexity of mitogen-activated protein kinases (MAPKs) made simple, Cell. Mol. Life Sci. 65 (2008) 3525-3544.

[79] G.D. Carystinos, M. Kandouz, M.A. Alaoui-Jamali, G. Batist, Unexpected induction of the human connexin 43 promoter by the ras signaling pathway is mediated by a novel putative promoter sequence, Mol. Pharmacol. 63 (2003) 821-831.

[80] G. Jia, G. Cheng, D.M. Gangahar, D.K. Agrawal, Involvement of connexin 43 in angiotensin II-induced migration and proliferation of saphenous vein smooth muscle cells via the MAPK-AP-1 signaling pathway, J. Mol. Cell. Cardiol. 44 (2008) 882-890.

[81] G. Jia, A.K. Mitra, G. Cheng. D.M. Gangahar, D.K. Agrawal, Angiotensin II and IGF-1 regulate connexin 43 expression via ERK and p38 signaling pathways in vascular smooth muscle cells of coronary artery bypass conduits, J. Surg. Res. 142 (2007) 137-142.

[82] J.A. Ko, R. Yanai, N. Morishige, T. Takezawa, T. Nishida, Upregulation of connexin43 expression in corneal fibroblasts by corneal epithelial cells, Invest. Ophthalmol Vis Sci. 50 (2009) 2054-2060.

[83] A. Salameh, S. Krautblatter, S. Baessler, S. Karl, D. Rojas Gomez, S. Dhein, D. Pfeiffer, Signal transduction and transcriptional control of cardiac connexin 43 up-regulation after alpha 1-adrenoceptor stimulation, J. Pharmacol. Exp. Ther. 326 (2008) 315-322.

[84] B. Nadarajah, H. Makarenkova, D.L. Becker, W.H. Evans, J.G. Parnavelas, Basic FGF increases communication between cells of the developing neocortex, J. Neurosci. 18 (1998) 7881-7890.

[85] C. Tacheau, J. Fontaine, J. Loy, A. Mauviel, F. Verrecchia, TGF-beta induces connexin 43 gene expression in normal murine mammary gland epithelial cells via activation of p38 and PI3K/AKT signaling pathways, J. Cell. Physiol. 217 (2008) 759-768.

[86] I. Granot, N. Dekel, Developmental expression and regulation of the gap junction protein and transcript in rat ovaries, Mol. Reprod. Dev. 47 (1997) 231-239.

[87] E. Oviedo-Orta, M. Perreau, W.H. Evans, I. Potolicchio, Control of the proliferation of activated CD4+ T cells by connexins, J. Leukoc. Biol. 88 (2010) 79-86.

[88] S.K. Koo, D.Y. Kim, S.D. Park, K.W. Kang, C.O. Joe, PKC phosphorylation disrupts gap junctional communication at G0/S phase in clone 9 cells, Mol. Cell. Biochem. 167 (1997) 41-49.

[89] X. Dang, M. Jeyaraman, E. Kardami, Regulation of connexin-43-mediated growth inhibition by a phosphorylatable amino-acid is independent of gap junctionforming ability, Mol. Cell. Biochem. 289 (2006) 201-207.

[90] E. Kardami, S. Banerji, B.W. Doble, X. Dang, R.R. Fandrich, Y. Jin, P.A. Cattini, PKCdependent phosphorylation may regulate the ability of connexin43 to inhibit DNA synthesis, Cell Commun. Adhes. 10 (2003) 293-297.

[91] J.L. Solan, M.D. Fry, E.M. TenBroek, P.D. Lampe, Connexin43 phosphorylation at S368 is acute during $\mathrm{S}$ and $\mathrm{G} 2 / \mathrm{M}$ and in response to protein kinase $\mathrm{C}$ activation, J. Cell Sci. 116 (2003) 2203-2211.

[92] M.Y. Kanemitsu, W. Jiang, W. Eckhart, Cdc2-mediated phosphorylation of the gap junction protein, connexin43, during mitosis, Cell Growth Differ. 9 (1998) $13-21$.

[93] I. Melchheier, C. von Montfort, D. Stuhlmann, H. Sies, L.O. Klotz, Quinoneinduced Cdc25A inhibition causes ERK-dependent connexin phosphorylation, Biochem. Biophys. Res. Commun. 327 (2005) 1016-1023. 
[94] R.P. Norris, M. Freudzon, LM. Mehlmann, AE Cowan, A.M. Simon, D.L. Paul, P.D. Lampe, L.A. Jaffe, Luteinizing hormone causes MAP kinase-dependent phosphorylation and closure of connexin 43 gap junctions in mouse ovarian follicles: one of two paths to meiotic resumption, Development 135 (2008) 3229-3238.

[95] S. Sela-Abramovich, E. Chorev, D. Galiani, N. Dekel, Mitogen-activated protein kinase mediates luteinizing hormone-induced breakdown of communication and oocyte maturation in rat ovarian follicles, Endocrinology 146 (2005) $1236-1244$.

96] K. Abdelmohsen, P.A. Gerber, C. von Montfort, H. Sies, L.O. Klotz, Epiderma growth factor receptor is a common mediator of quinone-induced signaling leading to phosphorylation of connexin-43: role of glutathione and tyrosine phosphatases, J. Biol. Chem. 278 (2003) 38360-38367.

97] S.J. Cameron, S. Malik, M. Akaike, N. Lerner-Marmarosh, C. Yan, J.D. Lee, J. Abe, J. Yang, Regulation of epidermal growth factor-induced connexin 43 gap junction communication by big mitogen-activated protein kinase1/ERK5 but not ERK1/2 kinase activation, J. Biol. Chem. 278 (2003) 18682-18688.

[98] G.T. Cottrell, R. Lin, B.J. Warn-Cramer, A.F. Lau, J.M. Burt, Mechanism of v-Src- and mitogen-activated protein kinase-induced reduction of gap junction communication, Am. J. Physiol Cell Physiol 284 (2003) C511-C520.

[99] M.Z. Hossain, P. Ao, A.L. Boynton, Platelet-derived growth factor-induced disruption of gap junctional communication and phosphorylation of connexin43 involves protein kinase $\mathrm{C}$ and mitogen-activated protein kinase, J. Cell. Physiol. 176 (1998) 332-341.

[100] M.Z. Hossain, A.B. Jagdale, P. Ao, A. Kazlauskas, A.L. Boynton, Disruption of gap junctional communication by the platelet-derived growth factor is mediated via multiple signaling pathways, J. Biol. Chem. 274 (1999) 10489-10496.

[101] L.O. Klotz, P. Patak, N. Ale-Agha, D.P. Buchczyk, K. Abdelmohsen, P.A. Gerber, C. von Montfort, H. Sies, 2-Methyl-1,4-naphthoquinone, vitamin K(3), decreases gap-junctional intercellular communication via activation of the epiderma growth factor receptor/extracellular signal-regulated kinase cascade, Cancer Res. 62 (2002) 4922-4928.

[102] P. Malone, H. Miao, A. Parker, S. Juarez, M.R. Hernandez, Pressure induces loss of gap junction communication and redistribution of connexin 43 in astrocytes, Glia 55 (2007) 1085-1098

[103] B. Mograbi, E. Corcelle, N. Defamie, M. Samson, M. Nebout, D. Segretain, P. Fenichel, G. Pointis, Aberrant Connexin 43 endocytosis by the carcinogen lindane involves activation of the ERK/mitogen-activated protein kinase pathway, Carcinogenesis 24 (2003) 1415-1423.

[104] J.H. Park, M.Y. Lee, J.S. Heo, H.J. Han, A potential role of connexin 43 in epidermal growth factor-induced proliferation of mouse embryonic stem cells: involvement of Ca2+/PKC, p44/42 and p38 MAPKs pathways, Cell Prolif. 41 (2008) 786-802.

[105] M.O. Kim, YJ. Lee, HJ. Han, Involvement of Cx43 phosphorylation in 5'-Nethylcarboxamide-induced migration and proliferation of mouse embryonic stem cells, J. Cell. Physiol. 224 (2010) 187-194.

[106] E. De Vuyst, E. Decrock, M. De Bock, H. Yamasaki, C.C. Naus, W.H. Evans, L Leybaert, Connexin hemichannels and gap junction channels are differentially influenced by lipopolysaccharide and basic fibroblast growth factor, Mol. Biol. Cell 18 (2007) 34-46.

[107] M.A. Retamal, N. Froger, N. Palacios-Prado, P. Ezan, P.J. Saez, J.C. Saez, C. Giaume Cx43 hemichannels and gap junction channels in astrocytes are regulated oppositely by proinflammatory cytokines released from activated microglia, J. Neurosci. 27 (2007) 13781-13792.

[108] K.A. Schalper, N. Palacios-Prado, M.A. Retamal, K.F. Shoji, A.D. Martinez, J.C. Saez, Connexin hemichannel composition determines the FGF-1-induced membrane permeability and free [Ca2+]i responses, Mol. Biol. Cell 19 (2008) 3501-3513.

[109] A. Muramatsu, M. Iwai, T. Morikawa, S. Tanaka, T. Mori, Y. Harada, T. Okanoue, Influence of transfection with connexin 26 gene on malignant potential of human hepatoma cells, Carcinogenesis 23 (2002) 351-358.

[110] Y. Nakano, M. Oyamada, P. Dai, T. Nakagami, S. Kinoshita, T. Takamatsu, Connexin43 knockdown accelerates wound healing but inhibits mesenchyma transition after corneal endothelial injury in vivo, Invest. Ophthalmol Vis Sci. 49 (2008) 93-104.

[111] C.C. Naus, K. Elisevich, D. Zhu, D.J. Belliveau, R.F. Del Maestro, In vivo growth of C6 glioma cells transfected with connexin43 cDNA, Cancer Res. 52 (1992) 4208-4213.

[112] G. Olbina, W. Eckhart, Mutations in the second extracellular region of connexin 43 prevent localization to the plasma membrane, but do not affect its ability to suppress cell growth, Mol. Cancer Res. 1 (2003) 690-700.

[113] Y. Omori, A. Duflot-Dancer, M. Mesnil, H. Yamasaki, Role of connexin (gap junction) genes in cell growth control: approach with site-directed mutagenesis and dominant-negative effects, Toxicol. Lett. 96-97 (1998) 105-110.

[114] Y. Omori, H. Yamasaki, Mutated connexin43 proteins inhibit rat glioma cell growth suppression mediated by wild-type connexin 43 in a dominant-negative manner, Int. J. Cancer 78 (1998) 446-453.

[115] Y. Omori, H. Yamasaki, Gap junction proteins connexin32 and connexin43 partially acquire growth-suppressive function in HeLa cells by deletion of their C-terminal tails, Carcinogenesis 20 (1999) 1913-1918.

[116] U.A. Oyoyo, U.S. Shah, S.A. Murray, The role of alpha1 (connexin-43) gap junction expression in adrenal cortical cell function, Endocrinology 138 (1997) 5385-5397.

[117] K.A. Peebles, M.W. Duncan, R.J. Ruch, A.M. Malkinson, Proteomic analysis of a neoplastic mouse lung epithelial cell line whose tumorigenicity has been abrogated by transfection with the gap junction structural gene for connexin 43 , Gja1, Carcinogenesis 24 (2003) 651-657.

[118] F. Princen, P. Robe, D. Gros, T. Jarry-Guichard, J. Gielen, M.P. Merville, V. Bours, Rat gap junction connexin-30 inhibits proliferation of glioma cell lines, Carcinogenesis 22 (2001) 507-513.
[119] G. Prost, F. Bernier-Valentin, Y. Munari-Silem, S. Selmi-Ruby, B. Rousset, Connexin-32 acts as a downregulator of growth of thyroid gland, Am. J. Physiol. Endocrinol. Metab. 294 (2008) E291-E299.

[120] A.A. Proulx, Z.X. Lin, C.C. Naus, Transfection of rhabdomyosarcoma cells with connexin43 induces myogenic differentiation, Cell Growth Differ. 8 (1997) 533-540.

[121] H. Qin, Q. Shao, H. Curtis, J. Galipeau, D.J. Belliveau, T. Wang, M.A. Alaoui-Jamali, D.W. Laird, Retroviral delivery of connexin genes to human breast tumor cells inhibits in vivo tumor growth by a mechanism that is independent of significant gap junctional intercellular communication, J. Biol. Chem. 277 (2002) 29132-29138.

[122] H. Qin, Q. Shao, T. Thomas, J. Kalra, M.A. Alaoui-Jamali, D.W. Laird, Connexin26 regulates the expression of angiogenesis-related genes in human breast tumor cells by both GJIC-dependent and -independent mechanisms, Cell Commun. Adhes. 10 (2003) 387-393.

[123] R.S. Rae, P.P. Mehta, C.C. Chang, J.E. Trosko, R.J. Ruch, Neoplastic phenotype of gapjunctional intercellular communication-deficient WB rat liver epithelial cells and its reversal by forced expression of connexin 32, Mol. Carcinog. 22 (1998) 120-127.

[124] C. Roger, B. Mograbi, D. Chevallier, J.F. Michiels, H. Tanaka, D. Segretain, G. Pointis, P. Fenichel, Disrupted traffic of connexin 43 in human testicular seminoma cells: overexpression of $\mathrm{Cx} 43$ induces membrane location and cell proliferation decrease, J. Pathol. 202 (2004) 241-246.

[125] R.J. Ruch, X. Guan, K. Sigler, Inhibition of gap junctional intercellular communication and enhancement of growth in BALB/c 3 T3 cells treated with connexin43 antisense oligonucleotides, Mol. Carcinog. 14 (1995) 269-274.

[126] H. Sato, K. Fukumoto, S. Hada, H. Hagiwara, E. Fujimoto, E. Negishi, K. Ueno, T. Yano, Enhancing effect of connexin 32 gene on vinorelbine-induced cytotoxicity in A549 lung adenocarcinoma cells, Cancer Chemother. Pharmacol. 60 (2007) 449-457.

[127] H. Sato, H. Hagiwara, Y. Ohde, H. Senba, N. Virgona, T. Yano, Regulation of rena cell carcinoma cell proliferation, invasion and metastasis by connexin 32 gene J. Membr. Biol. 216 (2007) 17-21.

[128] H. Sato, H. Hagiwara, H. Senba, K. Fukumoto, Y. Nagashima, H. Yamasaki, K. Ueno T. Yano, The inhibitory effect of connexin 32 gene on metastasis in renal cell carcinoma, Mol. Carcinog. 47 (2008) 403-409.

[129] H. Sato, H. Senba, N. Virgona, K. Fukumoto, T. Ishida, H. Hagiwara, E. Negishi, K. Ueno, H. Yamasaki, T. Yano, Connexin 32 potentiates vinblastine-induced cytotoxicity in renal cell carcinoma cells, Mol. Carcinog. 46 (2007) 215-224.

[130] Q. Shao, H. Wang, E. McLachlan, G.I. Veitch, D.W. Laird, Down-regulation of Cx43 by retroviral delivery of small interfering RNA promotes an aggressive breast cancer cell phenotype, Cancer Res. 65 (2005) 2705-2711.

[131] K. Shima, T. Muramatsu, Y. Abiko, Y. Yamaoka, H. Sasaki, M. Shimono, Connexin 43 transfection in basaloid squamous cell carcinoma cells, Oncol. Rep. 16 (2006) 285-288.

[132] S. Sridharan, L. Simon, D.D. Meling, D.G. Cyr, D.E. Gutstein, G.I. Fishman, F. Guillou, P.S. Cooke, Proliferation of adult sertoli cells following conditional knockout of the Gap junctional protein GJA1 (connexin 43) in mice, Biol. Reprod. 76 (2007) 804-812.

[133] M. Statuto, C. Audebet, H. Tonoli, S. Selmi-Ruby, B. Rousset, Y. Munari-Silem, Restoration of cell-to-cell communication in thyroid cell lines by transfection with and stable expression of the connexin-32 gene. Impact on cell proliferation and tissue-specific gene expression, J. Biol. Chem. 272 (1997) 24710-24716.

[134] M. Tanaka, H.B. Grossman, Connexin 26 induces growth suppression, apoptosis and increased efficacy of doxorubicin in prostate cancer cells, Oncol. Rep. 11 (2004) 537-541.

[135] M. Tanaka, H.B. Grossman, Connexin 26 gene therapy of human bladder cancer: induction of growth suppression, apoptosis, and synergy with Cisplatin, Hum. Gene Ther. 12 (2001) 2225-2236.

[136] A. Temme, A. Buchmann, H.D. Gabriel, E. Nelles, M. Schwarz, K. Willecke, High incidence of spontaneous and chemically induced liver tumors in mice deficient for connexin32, Curr. Biol. 7 (1997) 713-716.

[137] C. Vozzi, D. Bosco, E. Dupont, A. Charollais, P. Meda, Hyperinsulinemia-induced hypoglycemia is enhanced by overexpression of connexin 43, Endocrinology 138 (1997) 2879-2885.

[138] T. Yano, F.J. Hernandez-Blazquez, Y. Omori, H. Yamasaki, Reduction of malignant phenotype of HEPG 2 cell is associated with the expression of connexin 26 but not connexin 32, Carcinogenesis 22 (2001) 1593-1600.

[139] T. Yano, H. Yamasaki, Regulation of cellular invasion and matrix metalloproteinase activity in HepG2 cell by connexin 26 transfection, Mol. Carcinog. 31 (2001) 101-109.

[140] B.I. Yoon, Y. Hirabayashi, Y. Kawasaki, I. Tsuboi, T. Ott, Y. Kodama, J. Kanno, D.Y. Kim, K. Willecke, T. Inoue, Exacerbation of benzene pneumotoxicity in connexin 32 knockout mice: enhanced proliferation of CYP2E1-immunoreactive alveolar epithelial cells, Toxicology 195 (2004) 19-29.

[141] Y. Zhang, E.M. Kanter, J.G. Laing, C. Aprhys, D.C. Johns, E. Kardami, K.A. Yamada, Connexin43 expression levels influence intercellular coupling and cell proliferation of native murine cardiac fibroblasts, Cell Commun. Adhes. 15 (2008) 289-303.

[142] Y.W. Zhang, M. Kaneda, I. Morita, The gap junction-independent tumorsuppressing effect of connexin 43, J. Biol. Chem. 278 (2003) 44852-44856.

[143] Y.W. Zhang, I. Morita, M. Ikeda, K.W. Ma, S. Murota, Connexin43 suppresses proliferation of osteosarcoma U2OS cells through post-transcriptional regulation of p27, Oncogene 20 (2001) 4138-4149.

[144] Y.W. Zhang, K. Nakayama, K. Nakayama, I. Morita, A novel route for connexin 43 to inhibit cell proliferation: negative regulation of S-phase kinase-associated protein (Skp 2), Cancer Res. 63 (2003) 1623-1630.

[145] Z.Q. Zhang, W. Zhang, N.Q. Wang, M. Bani-Yaghoub, Z.X. Lin, C.C. Naus, Suppression of tumorigenicity of human lung carcinoma cells after transfection with connexin43, Carcinogenesis 19 (1998) 1889-1894. 
[146] D. Zhu, S. Caveney, G.M. Kidder, C.C. Naus, Transfection of C6 glioma cells with connexin 43 cDNA: analysis of expression, intercellular coupling, and cell proliferation, Proc. Natl Acad. Sci. USA 88 (1991) 1883-1887.

[147] D. Zhu, G.M. Kidder, S. Caveney, C.C. Naus, Growth retardation in glioma cells cocultured with cells overexpressing a gap junction protein, Proc. Natl Acad. Sci. USA 89 (1992) 10218-10221.

[148] S.R. Johnstone, A.K. Best, C.S. Wright, B.E. Isakson, R.J. Errington, P.E. Martin, Enhanced connexin 43 expression delays intra-mitotic duration and cell cycle traverse independently of gap junction channel function, J. Cell. Biochem. 110 (2010) 772-782.

[149] J.L. Avanzo, M. Mesnil, F.J. Hernandez-Blazquez, I.I. Mackowiak, C.M. Mori, T.C. da Silva, S.C. Oloris, A.P. Garate, S.M. Massironi, M.L. Dagli, Increased susceptibility to urethane-induced lung tumors in mice with decreased expression of connexin43, Carcinogenesis 25 (2004) 1973-1982.

[150] M.L. Dagli, H. Yamasaki, V. Krutovskikh, Y. Omori, Delayed liver regeneration and increased susceptibility to chemical hepatocarcinogenesis in transgenic mice expressing a dominant-negative mutant of connexin32 only in the liver, Carcinogenesis 25 (2004) 483-492.

[151] B. Eghbali, J.A. Kessler, L.M. Reid, C. Roy, D.C. Spray, Involvement of gap junctions in tumorigenesis: transfection of tumor cells with connexin 32 cDNA retards growth in vivo, Proc. Natl Acad. Sci. USA 88 (1991) 10701-10705.

[152] T.J. King, P.D. Lampe, Mice deficient for the gap junction protein Connexin32 exhibit increased radiation-induced tumorigenesis associated with elevated mitogen-activated protein kinase ( $\mathrm{p} 44 /$ Erk1, p42/Erk2) activation, Carcinogenesis 25 (2004) 669-680.

[153] E.G. Luebeck, A. Buchmann, D. Schneider, S.H. Moolgavkar, M. Schwarz, Modulation of liver tumorigenesis in Connexin32-deficient mouse, Mutat. Res. 570 (2005) 33-47.

[154] J.M. Burt, T.K. Nelson, A.M. Simon, J.S. Fang, Connexin 37 profoundly slows cell cycle progression in rat insulinoma cells, Am. J. Physiol. Cell Physiol. 295 (2008) C1103-C1112.

[155] V. Flachon, H. Tonoli, S. Selmi-Ruby, C. Durand, R. Rabilloud, B. Rousset, Y. Munari-Silem, Thyroid cell proliferation in response to forced expression of gap junction proteins, Eur. J. Cell Biol. 81 (2002) 243-252.

[156] G.S. Goldberg, J.F. Bechberger, Y. Tajima, M. Merritt, Y. Omori, M.A. Gawinowicz, R. Narayanan, Y. Tan, Y. Sanai, H. Yamasaki, C.C. Naus, H. Tsuda, B.J. Nicholson, Connexin43 suppresses MFG-E8 while inducing contact growth inhibition of glioma cells, Cancer Res. 60 (2000) 6018-6026.

[157] M. Mesnil, V. Krutovskikh, C. Piccoli, C. Elfgang, O. Traub, K. Willecke, H. Yamasaki, Negative growth control of HeLa cells by connexin genes: connexin species specificity, Cancer Res. 55 (1995) 629-639.

[158] D.L. Becker, P. Mobbs, Connexin alpha1 and cell proliferation in the developing chick retina, Exp. Neurol. 156 (1999) 326-332.

[159] C.E. Chadjichristos, C.M. Matter, I. Roth, E. Sutter, G. Pelli, T.F. Luscher, M. Chanson, B.R. Kwak, Reduced connexin43 expression limits neointima formation after balloon distension injury in hypercholesterolemic mice, Circulation 113 (2006) 2835-2843.

[160] M. Freidin, S. Asche, T.A. Bargiello, M.V. Bennett, C.K. Abrams, Connexin 32 increases the proliferative response of Schwann cells to neuregulin-1 ( $\mathrm{Nrg} 1)$, Proc. Natl Acad. Sci. USA 106 (2009) 3567-3572.

[161] A.D. Hoptak-Solga, S. Nielsen, I. Jain, R. Thummel, D.R. Hyde, M.K. Iovine, Connexin43 (GJA1) is required in the population of dividing cells during fin regeneration, Dev. Biol. 317 (2008) 541-548.

[162] M.C. Lim, G. Maubach, L. Zhuo, TGF-beta1 down-regulates connexin 43 expression and gap junction intercellular communication in rat hepatic stellate cells, Eur. J. Cell Biol. 88 (2009) 719-730.

[163] C.C. Naus, J.F. Bechberger, Y. Zhang, L. Venance, H. Yamasaki, S.C. Juneja, G.M. Kidder, C. Giaume, Altered gap junctional communication, intercellular signaling, and growth in cultured astrocytes deficient in connexin43, J. Neurosci. Res. 49 (1997) 528-540.

[164] S.C. Oloris, M. Mesnil, V.N. Reis, M. Sakai, P. Matsuzaki, S. Fonseca Ede, T.C. da Silva, J.L. Avanzo, I.L. Sinhorini, J.L. Guerra, F.A. Costa-Pinto, P.C. Maiorka, M.L. Dagli, Hepatic granulomas induced by Schistosoma mansoni in mice deficient for connexin 43 present lower cell proliferation and higher collagen content, Life Sci. 80 (2007) 1228-1235.

[165] H. Ozawa, H. Mutai, T. Matsunaga, Y. Tokumaru, M. Fujii, K. Sakamoto, T. Tomita, K. Ogawa, Promoted cell proliferation by connexin 30 gene transfection to head-and-neck cancer cell line, Anticancer Res. 29 (2009) 1981-1985.

[166] C. Sellitto, L. Li, T.W. White, Connexin50 is essential for normal postnatal lens cell proliferation, Invest. Ophthalmol Vis Sci. 45 (2004) 3196-3202.

[167] M. Song, X. Yu, X. Cui, G. Zhu, G. Zhao, J. Chen, L. Huang, Blockade of connexin 43 hemichannels reduces neointima formation after vascular injury by inhibiting proliferation and phenotypic modulation of smooth muscle cells, Exp. Biol. Med. 234 (2009) 1192-1200.

[168] M. Theis, D. Speidel, K. Willecke, Astrocyte cultures from conditional connexin43-deficient mice, Glia 46 (2004) 130-141.

[169] H.H. Wang, C.I. Kung, Y.Y. Tseng, Y.C. Lin, C.H. Chen, C.H. Tsai, H.I. Yeh, Activation of endothelial cells to pathological status by down-regulation of connexin43, Cardiovasc. Res. 79 (2008) 509-518.

[170] G.I. Veitch, J.E. Gittens, Q. Shao, D.W. Laird, G.M. Kidder, Selective assembly of connexin37 into heterocellular gap junctions at the oocyte/granulosa cell interface, J. Cell Sci. 117 (2004) 2699-2707.

[171] T. Ott, M. Jokwitz, D. Lenhard, A. Romualdi, F. Dombrowski, C. Ittrich, M. Schwarz, K. Willecke, Ablation of gap junctional communication in hepatocytes of transgenic mice does not lead to disrupted cellular homeo- stasis or increased spontaneous tumourigenesis, Eur. J. Cell Biol. 85 (2006) 717-728

[172] J.K. Chipman, A. Mally, G.O. Edwards, Disruption of gap junctions in toxicity and carcinogenicity, Toxicol. Sci. 71 (2003) 146-153.

[173] T. Kojima, A. Fort, M. Tao, M. Yamamoto, D.C. Spray, Gap junction expression and cell proliferation in differentiating cultures of Cx43 KO mouse hepatocytes, Am. J. Physiol. Gastrointest. Liver Physiol. 281 (2001) G1004-G1013.

[174] T. Yanagiya, A. Tanabe, K. Hotta, Gap-junctional communication is required for mitotic clonal expansion during adipogenesis, Obesity 15 (2007) 572-582.

[175] T. Nishimura, C. Dunk, Y. Lu, X. Feng, A. Gellhaus, E. Winterhager, J. Rossant, S.J. Lye, Gap junctions are required for trophoblast proliferation in early human placental development, Placenta 25 (2004) 595-607.

[176] A.H. Kihara, T.O. Santos, E.J. Osuna-Melo, V. Paschon, K.S. Vidal, P.S. Akamine, L.M. Castro, R.R. Resende, D.E. Hamassaki, L.R. Britto, Connexin-mediated communication controls cell proliferation and is essential in retinal histogenesis, Int. J. Dev. Neurosci. 28 (2010) 39-52.

[177] N. Uyama, Y. Shimahara, H. Okuyama, N. Kawada, S. Kamo, K. Ikeda, Y. Yamaoka, Carbenoxolone inhibits DNA synthesis and collagen gene expression in rat hepatic stellate cells in culture, J. Hepatol. 39 (2003) 749-755.

[178] W. Zhao, Z.X. Lin, Z.Q. Zhang, Cisplatin-induced premature senescence with concomitant reduction of gap junctions in human fibroblasts, Cell Res. 14 (2004) 60-66.

[179] J. Gilleron, D. Carette, P. Durand, G. Pointis, D. Segretain, Connexin 43 a potentia regulator of cell proliferation and apoptosis within the seminiferous epithelium, Int. J. Biochem. Cell Biol. 41 (2009) 1381-1390.

[180] W.A. Ciovacco, C.G. Goldberg, A.F. Taylor, J.M. Lemieux, M.C. Horowitz, H.J Donahue, M.A. Kacena, The role of gap junctions in megakaryocyte-mediated osteoblast proliferation and differentiation, Bone 44 (2009) 80-86.

[181] A. Tabernero, R. Sanchez-Alvarez, J.M. Medina, Increased levels of cyclins D1 and D3 after inhibition of gap junctional communication in astrocytes, J. Neurochem. 96 (2006) 973-982.

[182] S. Sela-Abramovich, I. Edry, D. Galiani, N. Nevo, N. Dekel, Disruption of gap junctional communication within the ovarian follicle induces oocyte maturation, Endocrinology 147 (2006) 2280-2286.

[183] M. Tsutsumi, K. Inoue, S. Denda, K. Ikeyama, M. Goto, M. Denda, Mechanicalstimulation-evoked calcium waves in proliferating and differentiated human keratinocytes, Cell Tissue Res. 338 (2009) 99-106.

[184] C.L. Liu, Y.S. Huang, M. Hosokawa, K. Miyashita, M.L. Hu, Inhibition of proliferation of a hepatoma cell line by fucoxanthin in relation to cell cycle arrest and enhanced gap junctional intercellular communication, Chem. Biol. Interact. 182 (2009) 165-172.

[185] P.J. Stork, J.M. Schmitt, Crosstalk between cAMP and MAP kinase signaling in the regulation of cell proliferation, Trends Cell Biol. 12 (2002) 258-266.

[186] R.P. Norris, W.J. Ratzan, M. Freudzon, L.M. Mehlmann, J. Krall, M.A. Movsesian, H. Wang, H. Ke, V.O. Nikolaev, L.A. Jaffe, Cyclic GMP from the surrounding somatic cells regulates cyclic AMP and meiosis in the mouse oocyte, Development 136 (2009) 1869-1878.

[187] S. Vaccari, K. Horner, L.M. Mehlmann, M. Conti, Generation of mouse oocytes defective in cAMP synthesis and degradation: endogenous cyclic AMP is essential for meiotic arrest, Dev. Biol. 316 (2008) 124-134.

[188] M.J. Berridge, Inositol trisphosphate and calcium signalling mechanisms, Biochim. Biophys. Acta 1793 (2009) 933-940.

[189] J.P. Stains, R. Civitelli, Gap junctions regulate extracellular signal-regulated kinase signaling to affect gene transcription, Mol. Biol. Cell 16 (2005) 64-72.

[190] J.P. Stains, R. Civitelli, Cell-to-cell interactions in bone, Biochem. Biophys. Res. Commun. 328 (2005) 721-727.

[191] J.P. Stains, F. Lecanda, J. Screen, D.A. Towler, R. Civitelli, Gap junctional communication modulates gene transcription by altering the recruitment of Sp1 and Sp3 to connexin-response elements in osteoblast promoters, J. Biol. Chem. 278 (2003) 24377-24387.

[192] S. Pollok, A.C. Pfeiffer, R. Lobmann, C.S. Wright, I. Moll, P.E. Martin, J.M. Brandner, Connexin 43 mimetic peptide Gap27 reveals potential differences in the role of Cx43 in wound repair between diabetic and non-diabetic cells, J Cell Mol Med: (2010) doi:10.1111/j.1582-4934.2010.01057.x.

[193] D.J. Belliveau, M. Bani-Yaghoub, B. McGirr, C.C. Naus, W.J. Rushlow, Enhanced neurite outgrowth in PC12 cells mediated by connexin hemichannels and ATP, J. Biol. Chem. 281 (2006) 20920-20931.

[194] G.M. Essenfelder, R. Bruzzone, J. Lamartine, A. Charollais, C. Blanchet-Bardon, M. T. Barbe, P. Meda, G. Waksman, Connexin30 mutations responsible for hidrotic ectodermal dysplasia cause abnormal hemichannel activity, Hum. Mol. Genet. 13 (2004) 1703-1714.

[195] T.A. Weissman, P.A. Riquelme, L. Ivic, A.C. Flint, A.R. Kriegstein, Calcium waves propagate through radial glial cells and modulate proliferation in the developing neocortex, Neuron 43 (2004) 647-661.

[196] R.A. Pearson, N. Dale, E. Llaudet, P. Mobbs, ATP released via gap junction hemichannels from the pigment epithelium regulates neural retinal progenitor proliferation, Neuron 46 (2005) 731-744.

[197] R.A. Pearson, N.L. Luneborg, D.L. Becker, P. Mobbs, Gap junctions modulate interkinetic nuclear movement in retinal progenitor cells, J. Neurosci. 25 (2005) 10803-10814.

[198] X. Liu, K. Hashimoto-Torii, M. Torii, C. Ding, P. Rakic, Gap junctions/hemichannels modulate interkinetic nuclear migration in the forebrain precursors, J. Neurosci. 30 (2010) 4197-4209.

[199] M.V. Bennett, J.E. Contreras, F.F. Bukauskas, J.C. Saez, New roles for astrocytes: gap junction hemichannels have something to communicate, Trends Neurosci. 26 (2003) 610-617. 
[200] A. De Flora, E. Zocchi, L. Guida, L. Franco, S. Bruzzone, Autocrine and paracrine calcium signaling by the CD38/NAD+/cyclic ADP-ribose system, Ann. NY Acad. Sci. 1028 (2004) 176-191.

[201] L. Franco, E. Zocchi, C. Usai, L. Guida, S. Bruzzone, A. Costa, A. De Flora, Paracrine roles of NAD + and cyclic ADP-ribose in increasing intracellular calcium and enhancing cell proliferation of 3 T3 fibroblasts, J. Biol. Chem. 276 (2001) 21642-21648.

[202] D.A. Goodenough, D.L. Paul, Beyond the gap: functions of unpaired connexon channels, Nat. Rev. Mol. Cell Biol. 4 (2003) 285-294.

[203] S. Bruzzone, L. Franco, L. Guida, E. Zocchi, P. Contini, A. Bisso, C. Usai, A. De Flora, A self-restricted CD38-connexin 43 cross-talk affects NAD + and cyclic ADP-ribose metabolism and regulates intracellular calcium in $3 \mathrm{~T} 3$ fibroblasts, J. Biol. Chem. 276 (2001) 48300-48308.

[204] A. Bier, I. Oviedo-Landaverde, J. Zhao, Y. Mamane, M. Kandouz, G. Batist, Connexin43 pseudogene in breast cancer cells offers a novel therapeutic target, Mol. Cancer Ther. 8 (2009) 786-793.

[205] S.L. Bond, J.F. Bechberger, N.K. Khoo, C.C. Naus, Transfection of C6 glioma cells with connexin32: the effects of expression of a nonendogenous gap junction protein, Cell Growth Differ. 5 (1994) 179-186.

[206] X. Dang, B.W. Doble, E. Kardami, The carboxy-tail of connexin-43 localizes to the nucleus and inhibits cell growth, Mol. Cell. Biochem. 242 (2003) 35-38.

[207] B.W. Doble, X. Dang, P. Ping, R.R. Fandrich, B.E. Nickel, Y. Jin, P.A. Cattini, E. Kardami, Phosphorylation of serine 262 in the gap junction protein connexin- 43 regulates DNA synthesis in cell-cell contact forming cardiomyocytes, J. Cell Sci. 117 (2004) 507-514.

[208] A. Duflot-Dancer, M. Mesnil, H. Yamasaki, Dominant-negative abrogation of connexin-mediated cell growth control by mutant connexin genes, Oncogene 15 (1997) 2151-2158.

[209] E. Fujimoto, H. Satoh, E. Negishi, K. Ueno, Y. Nagashima, K. Hagiwara, H. Yamasaki, T. Yano, Negative growth control of renal cell carcinoma cell by connexin 32: possible involvement of Her-2, Mol. Carcinog. 40 (2004) 135-142.

[210] R.P. Huang, Y. Fan, M.Z. Hossain, A. Peng, Z.L. Zeng, A.L. Boynton, Reversion of the neoplastic phenotype of human glioblastoma cells by connexin 43 (cx43) Cancer Res. 58 (1998) 5089-5096.

[211] M. Ionta, R.A. Ferreira, S.C. Pfister, G.M. Machado-Santelli, Exogenous Cx43 expression decrease cell proliferation rate in rat hepatocarcinoma cells independently of functional gap junction, Cancer Cell Int. 9 (2009) 22.

[212] J. Kalra, Q. Shao, H. Qin, T. Thomas, M.A. Alaoui-Jamali, D.W. Laird, Cx26 inhibits breast MDA-MB-435 cell tumorigenic properties by a gap junctional intercellular communication-independent mechanism, Carcinogenesis 27 (2006) 2528-2537.

[213] M. Kandouz, A. Bier, G.D. Carystinos, M.A. Alaoui-Jamali, G. Batist, Connexin43 pseudogene is expressed in tumor cells and inhibits growth, Oncogene 23 (2004) 4763-4770.

[214] V.A. Krutovskikh, S.M. Troyanovsky, C. Piccoli, H. Tsuda, M. Asamoto, H. Yamasaki, Differential effect of subcellular localization of communication impairing gap junction protein connexin43 on tumor cell growth in vivo, Oncogene 19 (2000) 505-513.

[215] C. Moorby, M. Patel, Dual functions for connexins: Cx43 regulates growt independently of gap junction formation, Exp. Cell Res. 271 (2001) 238-248.

[216] S.C. Chen, D.B. Pelletier, P. Ao, A.L. Boynton, Connexin43 reverses the phenotype of transformed cells and alters their expression of cyclin/cyclin-dependent kinases, Cell Growth Differ. 6 (1995) 681-690.

[217] E. Fujimoto, H. Sato, Y. Nagashima, E. Negishi, S. Shirai, K. Fukumoto, H. Hagiwara, K. Hagiwara, K. Ueno, T. Yano, A Src family inhibitor (PP1) potentiates tumor-suppressive effect of connexin 32 gene in renal cancer cells, Life Sci. 76 (2005) 2711-2720.

[218] T.J. King, K.E. Gurley, J. Prunty, J.L. Shin, C.J. Kemp, P.D. Lampe, Deficiency in the gap junction protein connexin32 alters p27Kip1 tumor suppression and MAPK activation in a tissue-specific manner Oncogene 24 (2005) 1718-1726.

[219] T.J. King, P.D. Lampe, Altered tumor biology and tumorigenesis in irradiated and chemical carcinogen-treated single and combined connexin32/p27Kip1-deficient mice, Cell Commun. Adhes. 12 (2005) 293-305.

[220] L. Koffler, S. Roshong, I. Kyu Park, K. Cesen-Cummings, D.C. Thompson, L.D. Dwyer-Nield, P. Rice, C. Mamay, A.M. Malkinson, R.J. Ruch, Growth inhibition in $\mathrm{G}(1)$ and altered expression of cyclin D1 and p27(kip-1)after forced connexin expression in lung and liver carcinoma cells, J. Cell. Biochem. 79 (2000) 347-354.

[221] D. Matsuyama, K. Kawahara, Proliferation of neonatal cardiomyocytes by connexin43 knockdown via synergistic inactivation of p38 MAPK and increased expression of FGF1, Basic Res. Cardiol. 104 (2009) 631-642.

[222] R. Huang, Y. Lin, C.C. Wang, J. Gano, B. Lin, Q. Shi, A. Boynton, J. Burke, R.P. Huang Connexin 43 suppresses human glioblastoma cell growth by down-regulation of monocyte chemotactic protein 1 , as discovered using protein array technology Cancer Res. 62 (2002) 2806-2812.

[223] X. Li, Y.B. Xu, Q. Wang, Y. Lu, Y. Zheng, Y.C. Wang, M. Lubbert, K.W. Zhao, G.Q. Chen, Leukemogenic AML1-ETO fusion protein upregulates expression of connexin 43: the role in AML 1-ETO-induced growth arrest in leukemic cells, J. Cell. Physiol. 208 (2006) 594-601.

[224] T. Akiyama, Wnt/beta-catenin signaling, Cytokine Growth Factor Rev. 11 (2000) 273-282.

[225] R.H. Giles, J.H. van Es, H. Clevers, Caught up in a Wnt storm: Wnt signaling in cancer, Biochim. Biophys. Acta 1653 (2003) 1-24

[226] B.T. MacDonald, K. Tamai, X. He, Wnt/beta-catenin signaling: components, mechanisms, and diseases, Dev. Cell 17 (2009) 9-26.

[227] C. Sharpe, N. Lawrence, A. Martinez Arias, Wnt signalling: a theme with nuclear variations, Bioessays 23 (2001) 311-318.

[228] Y. Zhai, R. Wu, D.R. Schwartz, D. Darrah, H. Reed, F.T. Kolligs, M.T. Nieman, E.R Fearon, K.R. Cho, Role of beta-catenin/T-cell factor-regulated genes in ovarian endometrioid adenocarcinomas, Am. J. Pathol. 160 (2002) 1229-1238.
[229] G. Davidson, J. Shen, Y.L. Huang, Y. Su, E. Karaulanov, K. Bartscherer, C. Hassler, P. Stannek, M. Boutros, C. Niehrs, Cell cycle control of wnt receptor activation, Dev. Cell 17 (2009) 788-799.

[230] Z. Ai, A. Fischer, D.C. Spray, A.M. Brown, G.I. Fishman, Wnt-1 regulation of connexin43 in cardiac myocytes, J. Clin. Invest. 105 (2000) 161-171.

[231] J. Kamei, T. Toyofuku, M. Hori, Negative regulation of p21 by beta-catenin/TCF signaling: a novel mechanism by which cell adhesion molecules regulate cell proliferation, Biochem. Biophys. Res. Commun. 312 (2003) 380-387.

[232] M.A. van der Heyden, M.B. Rook, M.M. Hermans, G. Rijksen, J. Boonstra, L.H. Defize, O.H. Destree, Identification of connexin43 as a functional target for Wnt signalling, J. Cell Sci. 111 (1998) 1741-1749.

[233] T. Constantinou, F. Baumann, M.D. Lacher, S. Saurer, R. Friis, A. Dharmarajan, SFRP-4 abrogates Wnt-3a-induced beta-catenin and Akt/PKB signalling and reverses a Wnt-3a-imposed inhibition of in vitro mammary differentiation, J. Mol. Signaling 3 (2008) 10.

[234] J. Czyz, K. Guan, Q. Zeng, A.M. Wobus, Loss of beta 1 integrin function results in upregulation of connexin expression in embryonic stem cell-derived cardiomyocytes, Int. J. Dev. Biol. 49 (2005) 33-41.

[235] W.J. Du, J.K. Li, Q.Y. Wang, J.B. Hou, B. Yu, Lithium chloride regulates connexin43 in skeletal myoblasts in vitro: possible involvement in Wnt/beta-catenin signaling, Cell Commun. Adhes. 15 (2008) 261-271.

[236] M. Kuwabara, Y. Kakinuma, R.G. Katare, M. Ando, F. Yamasaki, Y. Doi, T. Sato, Granulocyte colony-stimulating factor activates Wnt signal to sustain gap junction function through recruitment of beta-catenin and cadherin, FEBS Lett. 581 (2007) 4821-4830.

[237] X. Liu, W. Liu, L. Yang, B. Xia, J. Li, J. Zuo, X. Li, Increased connexin 43 expression improves the migratory and proliferative ability of H9c2 cells by Wnt-3a overexpression, Acta Biochim. Biophys. Sin. 39 (2007) 391-398.

[238] R.A. Meyer, M.F. Cohen, S. Recalde, J. Zakany, S.M. Bell, W.J. Scott Jr., C.W Lo, Developmental regulation and asymmetric expression of the gene encoding Cx43 gap junctions in the mouse limb bud, Dev. Genet. 21 (1997) 290-300.

[239] J.A. Robinson, M. Chatterjee-Kishore, P.J. Yaworsky, D.M. Cullen, W. Zhao, C. Li, Y. Kharode, L. Sauter, P. Babij, E.L. Brown, A.A. Hill, M.P. Akhter, M.L. Johnson, R.R Recker, B.S. Komm, F.J. Bex, Wnt/beta-catenin signaling is a normal physiological response to mechanical loading in bone, J. Biol. Chem. 281 (2006) 31720-31728.

[240] I. Samarzija, P. Sini, T. Schlange, G. Macdonald, N.E. Hynes, Wnt3a regulates proliferation and migration of HUVEC via canonical and non-canonical Wnt signaling pathways, Biochem. Biophys. Res. Commun. 386 (2009) 449-454.

[241] A. Santos, A.D. Bakker, B. Zandieh-Doulabi, C.M. Semeins, J. Klein-Nulend, Pulsating fluid flow modulates gene expression of proteins involved in Wnt signaling pathways in osteocytes, J. Orthop. Res. 27 (2009) 1280-1287.

[242] W.J. Du, J.K. Li, Q.Y. Wang, J.B. Hou, B. Yu, Lithium chloride preconditioning optimizes skeletal myoblast functions for cellular cardiomyoplasty in vitro via glycogen synthase kinase-3beta/beta-catenin signaling, Cells Tissues Organs 190 (2009) 11-19.

[243] H.S. Duffy, M. Delmar, D.C. Spray, Formation of the gap junction nexus: binding partners for connexins, J. Physiol. Paris 96 (2002) 243-249.

[244] B.N. Giepmans, Gap junctions and connexin-interacting proteins, Cardiovasc. Res. 62 (2004) 233-245.

[245] C. Nambara, Y. Kawasaki, H. Yamasaki, Role of the cytoplasmic loop domain of $\mathrm{Cx} 43$ in its intracellular localization and function: possible interaction with cadherin, J. Membr. Biol. 217 (2007) 63-69.

[246] M.A. Thomas, S. Huang, A. Cokoja, O. Riccio, O. Staub, S. Suter, M. Chanson, Interaction of connexins with protein partners in the control of channel turnover and gating, Biol. Cell 94 (2002) 445-456.

[247] S. Chakraborty, S. Mitra, M.M. Falk, S.H. Caplan, M.J. Wheelock, K.R. Johnson, P.P. Mehta, E-cadherin differentially regulates the assembly of Connexin43 and Connexin32 into gap junctions in human squamous carcinoma cells, J. Biol. Chem. 285 (2010) 10761-10776.

[248] F.J. Hernandez-Blazquez, P.P. Joazeiro, Y. Omori, H. Yamasaki, Control of intracellular movement of connexins by E-cadherin in murine skin papilloma cells, Exp. Cell Res. 270 (2001) 235-247.

249] M. Hsu, T. Andl, G. Li, J.L. Meinkoth, M. Herlyn, Cadherin repertoire determines partner-specific gap junctional communication during melanoma progression, J. Cell Sci. 113 (2000) 1535-1542.

[250] W.M. Jongen, D.J. Fitzgerald, M. Asamoto, C. Piccoli, T.J. Slaga, D. Gros, M Takeichi, H. Yamasaki, Regulation of connexin 43-mediated gap junctional intercellular communication by $\mathrm{Ca} 2+$ in mouse epidermal cells is controlled by E-cadherin, J. Cell Biol. 114 (1991) 545-555.

[251] J. Li, V.V. Patel, I. Kostetskii, Y. Xiong, A.F. Chu, J.T. Jacobson, C. Yu, G.E. Morley, J.D Molkentin, G.L. Radice, Cardiac-specific loss of N-cadherin leads to alteration in connexins with conduction slowing and arrhythmogenesis, Circ. Res. 97 (2005) 474-481.

[252] T. Matsuda, Y. Fujio, T. Nariai, T. Ito, M. Yamane, T. Takatani, K. Takahashi, J. Azuma, N-cadherin signals through Rac1 determine the localization of connexin 43 in cardiac myocytes, J. Mol. Cell. Cardiol. 40 (2006) 495-502.

[253] R.A. Meyer, D.W. Laird, J.P. Revel, R.G. Johnson, Inhibition of gap junction and adherens junction assembly by connexin and A-CAM antibodies, J. Cell Biol. 119 (1992) 179-189.

[254] M. Nishimura, T. Saito, H. Yamasaki, R. Kudo, Suppression of gap junctional intercellular communication via $5^{\prime} \mathrm{CpG}$ island methylation in promoter region of $\mathrm{E}-$ cadherin gene in endometrial cancer cells, Carcinogenesis 24 (2003) 1615-1623.

[255] D.M. Prowse, G.P. Cadwallader, J.D. Pitts, E-cadherin expression can alter the specificity of gap junction formation, Cell Biol. Int. 21 (1997) 833-843. 
[256] C.J. Wei, R. Francis, X. Xu, C.W. Lo, Connexin43 associated with an N-cadherincontaining multiprotein complex is required for gap junction formation in NIH3T3 cells, J. Biol. Chem. 280 (2005) 19925-19936.

[257] K. Fujimoto, A. Nagafuchi, S. Tsukita, A. Kuraoka, A. Ohokuma, Y. Shibata, Dynamics of connexins, E-cadherin and alpha-catenin on cell membranes during gap junction formation, J Cell Sci 110 (1997) 311-322.

[258] H.T. Xu, Q.C. Li, Y.X. Zhang, Y. Zhao, Y. Liu, Z.Q. Yang, E.H. Wang, Connexin 43 recruits E-cadherin expression and inhibits the malignant behaviour of lung cancer cells, Folia Histochem. Cytobiol. 46 (2008) 315-321.

[259] N. Gupta, H. Wang, T.L. McLeod, C.C. Naus, S. Kyurkchiev, S. Advani, J. Yu, B. Perbal, R.R. Weichselbaum, Inhibition of glioma cell growth and tumorigenic potential by CCN3 (NOV), Mol. Pathol. 54 (2001) 293-299.

[260] T.L. McLeod, J.F. Bechberger, C.C. Naus, Determination of a potential role of the CCN family of growth regulators in connexin 43 transfected C6 glioma cells, Cell Commun. Adhes. 8 (2001) 441-445.

[261] C.C. Naus, S.L. Bond, J.F. Bechberger, W. Rushlow, Identification of genes differentially expressed in C6 glioma cells transfected with connexin43, Brain Res. Brain Res. Rev. 32 (2000) 259-266.

[262] W.C. Sin, J.F. Bechberger, W.J. Rushlow, C.C. Naus, Dose-dependent differential upregulation of CCN1/Cyr61 and CCN3/NOV by the gap junction protein Connexin43 in glioma cells, J. Cell. Biochem. 103 (2008) 1772-1782.

[263] C.T. Fu, J.F. Bechberger, M.A. Ozog, B. Perbal, C.C. Naus, CCN3 (NOV) interacts with connexin43 in C6 glioma cells: possible mechanism of connexin-mediated growth suppression, J. Biol. Chem. 279 (2004) 36943-36950.

[264] A. Gellhaus, X. Dong, S. Propson, K. Maass, L. Klein-Hitpass, M. Kibschull, O. Traub, K. Willecke, B. Perbal, S.J. Lye, E. Winterhager, Connexin43 interacts with NOV: a possible mechanism for negative regulation of cell growth in choriocarcinoma cells, J. Biol. Chem. 279 (2004) 36931-36942.

[265] A. Gellhaus, C. Wotzlaw, T. Otto, J. Fandrey, E. Winterhager, More insights into the CCN3/Connexin43 interaction complex and its role for signaling, J. Cell. Biochem. 110 (2010) 129-140.

[266] C.C. Chen, L.F. Lau, Functions and mechanisms of action of CCN matricellular proteins, Int. J. Biochem. Cell Biol. 41 (2009) 771-783.

[267] X. Li, M. Penes, B. Odermatt, K. Willecke, J.I. Nagy, Ablation of Cx47 in transgenic mice leads to the loss of MUPP1, ZONAB and multiple connexins at oligodendrocyte-astrocyte gap junctions, Eur. J. Neurosci. 28 (2008) 1503-1517.

[268] M.C. Penes, X. Li, J.I. Nagy, Expression of zonula occludens-1 (ZO-1) and the transcription factor ZO-1-associated nucleic acid-binding protein (ZONAB)MsY3 in glial cells and colocalization at oligodendrocyte and astrocyte gap junctions in mouse brain, Eur. J. Neurosci. 22 (2005) 404-418

[269] T. Sourisseau, A. Georgiadis, A. Tsapara, R.R. Ali, R. Pestell, K. Matter, M.S. Balda, Regulation of PCNA and cyclin D1 expression and epithelial morphogenesis by the ZO-1-regulated transcription factor ZONAB/DbpA, Mol. Cell. Biol. 26 (2006) 2387-2398.

[270] M.S. Balda, M.D. Garrett, K. Matter, The ZO-1-associated Y-box factor ZONAB regulates epithelial cell proliferation and cell density, J. Cell Biol. 160 (2003) 423-432.

[271] K. Matter, M.S. Balda, Signalling to and from tight junctions, Nat. Rev. Mol. Cell Biol. 4 (2003) 225-236.

[272] P. Frankel, A. Aronheim, E. Kavanagh, M.S. Balda, K. Matter, T.D. Bunney, C.J. Marshall, RalA interacts with ZONAB in a cell density-dependent manner and regulates its transcriptional activity, EMBO J. 24 (2005) 54-62.

[273] A. Tsapara, K. Matter, M.S. Balda, The heat-shock protein Apg-2 binds to the tight junction protein ZO-1 and regulates transcriptional activity of ZONAB, Mol. Biol. Cell 17 (2006) 1322-1330.

[274] M. Buchert, C. Darido, E. Lagerqvist, A. Sedello, C. Cazevieille, F. Buchholz, J.F. Bourgaux, J. Pannequin, D. Joubert, F. Hollande, The symplekin/ZONAB complex inhibits intestinal cell differentiation by the repression of AML1/Runx1, Gastroenterology 137 (2009) 156-164.

[275] E. Kavanagh, M. Buchert, A. Tsapara, A. Choquet, M.S. Balda, F. Hollande, K. Matter, Functional interaction between the ZO-1-interacting transcription factor
ZONAB/DbpA and the RNA processing factor symplekin, J. Cell Sci. 119 (2006) 5098-5105.

[276] M. Nie, S. Aijaz, I.V. Leefa Chong San, M.S. Balda, K. Matter, The Y-box factor ZONAB/DbpA associates with GEF-H1/Lfc and mediates Rho-stimulated transcription, EMBO Rep. 10 (2009) 1125-1131.

[277] D. Singh, J.L. Solan, S.M. Taffet, R. Javier, P.D. Lampe, Connexin 43 interacts with zona occludens- 1 and -2 proteins in a cell cycle stage-specific manner, J. Biol. Chem. 280 (2005) 30416-30421.

[278] A. Betanzos, M. Huerta, E. Lopez-Bayghen, E. Azuara, J. Amerena, L. GonzalezMariscal, The tight junction protein ZO-2 associates with Jun, Fos and C/EBP transcription factors in epithelial cells, Exp Cell Res 292 (2004) 51-66.

[279] S. Islas, J. Vega, L. Ponce, L. Gonzalez-Mariscal, Nuclear localization of the tight junction protein ZO-2 in epithelial cells, Exp. Cell Res. 274 (2002) 138-148.

[280] B.E. Jaramillo, A. Ponce, J. Moreno, A. Betanzos, M. Huerta, E. Lopez-Bayghen, L. Gonzalez-Mariscal, Characterization of the tight junction protein ZO-2 localized at the nucleus of epithelial cells, Exp. Cell Res. 297 (2004) 247-258.

[281] R. Tapia, M. Huerta, S. Islas, A. Avila-Flores, E. Lopez-Bayghen, J. Weiske, O. Huber, L. Gonzalez-Mariscal, Zona occludens-2 inhibits cyclin D1 expression and cell proliferation and exhibits changes in localization along the cell cycle, Mol. Biol. Cell 20 (2009) 1102-1117.

[282] M. Huerta, R. Munoz, R. Tapia, E. Soto-Reyes, L. Ramirez, F. Recillas-Targa, L. Gonzalez-Mariscal, E. Lopez-Bayghen, Cyclin D1 is transcriptionally downregulated by ZO-2 via an E box and the transcription factor c-Myc, Mol. Biol. Cell 18 (2007) 4826-4836.

[283] H.S. Duffy, I. Iacobas, K. Hotchkiss, B.J. Hirst-Jensen, A. Bosco, N. Dandachi, R. Dermietzel, P.L. Sorgen, D.C. Spray, The gap junction protein connexin32 interacts with the Src homology 3/hook domain of discs large homolog 1 , J. Biol. Chem. 282 (2007) 9789-9796.

[284] B.A. MacVicar, R.J. Thompson, Non-junction functions of pannexin-1 channels, Trends Neurosci. 33 (2010) 93-102.

[285] V.I. Shestopalov, Y. Panchin, Pannexins and gap junction protein diversity, Cell. Mol. Life Sci. 65 (2008) 376-394.

[286] C.P. Lai, J.F. Bechberger, R.J. Thompson, B.A. MacVicar, R. Bruzzone, C.C. Naus, Tumor-suppressive effects of pannexin 1 in C6 glioma cells, Cancer Res. 67 (2007) 1545-1554.

[287] C.P. Lai, J.F. Bechberger, C.C. Naus, Pannexin2 as a novel growth regulator in C6 glioma cells, Oncogene 28 (2009) 4402-4408.

[288] U. Schenk, A.M. Westendorf, E. Radaelli, A. Casati, M. Ferro, M. Fumagalli, C. Verderio, J. Buer, E. Scanziani, F. Grassi, Purinergic control of T cell activation by ATP released through pannexin-1 hemichannels, Sci. Signal. 1 (2008) ra6.

[289] M. Nishida, Y. Sato, A. Uemura, Y. Narita, H. Tozaki-Saitoh, M. Nakaya, T. Ide, K. Suzuki, K. Inoue, T. Nagao, $\mathrm{H}$. Kurose, P2Y6 receptor-Galpha12/13 signalling in cardiomyocytes triggers pressure overload-induced cardiac fibrosis, EMBO J. 27 (2008) 3104-3115.

[290] T. Iwamoto, T. Nakamura, A. Doyle, M. Ishikawa, S. de Vega, S. Fukumoto, Y. Yamada, Pannexin 3 regulates intracellular ATP/cAMP levels and promotes chondrocyte differentiation, J. Biol. Chem. 285 (2010) 18948-18958.

[291] D. Locke, S. Bian, H. Li, A.L. Harris, Post-translational modifications of connexin26 revealed by mass spectrometry, Biochem. J. 424 (2009) 385-398.

[292] S. Penuela, R. Bhalla, X.Q. Gong, K.N. Cowan, S.J. Celetti, B.J. Cowan, D. Bai, Q. Shao, D.W. Laird, Pannexin 1 and pannexin 3 are glycoproteins that exhibit many distinct characteristics from the connexin family of gap junction proteins, J. Cell Sci. 120 (2007) 3772-3783.

[293] S. Penuela, R. Bhalla, K. Nag, D.W. Laird, Glycosylation regulates pannexin intermixing and cellular localization, Mol. Biol. Cell 20 (2009) 4313-4323.

[294] D.C. Spray, Z.C. Ye, B.R. Ransom, Functional connexin "hemichannels": a critical appraisal, Glia 54 (2006) 758-773.

[295] L. Leybaert, K. Braet, W. Vandamme, L. Cabooter, P.E. Martin, W.H. Evans, Connexin channels, connexin mimetic peptides and ATP release, Cell Commun. Adhes. 10 (2003) 251-257. 